\title{
A PILOT STUDY EXAMINING HIGH SCHOOL PHYSICAL EDUCATION TEACHERS' UNDERSTANDING AND USE OF MOSSTON'S STYLE (S) OF TEACHING
}

\author{
A Thesis \\ Presented to \\ The Faculty of California Polytechnic State University, \\ San Luis Obispo
}

\author{
In Partial Fulfillment \\ of the Requirements for the Degree \\ Master of Science in Kinesiology \\ By
}

Gregory Lovick Pierce

December 2010 
(C) 2010

Gregory Lovick Pierce

All Rights Reserved 


\section{COMMITTEE MEMBERSHIP}

TITLE: A Pilot Study Examining High School Physical Education Teachers' Understanding and Use of Mosston's Style(s) of Teaching

AUTHOR: Gregory Lovick Pierce

DATE SUBMITTED: December 2010

Committee Chair: Dr. Kellie Green-Hall, Ph.D.

Committee Member: Dr. Camille O’Bryant, Ph.D.

Committee Member: Dr. Gerald DeMers, Ph.D. 


\begin{abstract}
A Pilot Study Examining High School Physical Education Teachers' Understanding and Use of Mosston's Style(s) of Teaching

By Gregory Lovick Pierce
\end{abstract}

The purpose of this project was to develop a questionnaire that could lend insight to physical educations teachers' perceptions and use of Mosston's Teaching Styles. The researcher designed a pilot study in which he distributed the questionnaire to six teachers from three Santa Barbara District High Schools. Results show that the six teachers were familiar with all Mosston's Styles. However, citing circumstances such as class time and class sizes, the participants in this study did not use all of Mosston's Styles. These results may be useful for physical education teacher educators to help them understand teachers' knowledge of Mosston's Styles, and what they can do to help teachers by giving them strategies to help use different teaching styles, despite reasons such as limited time and large class sizes. 


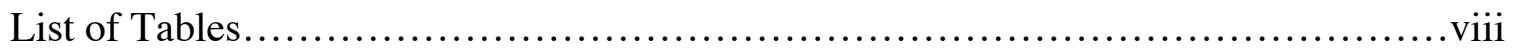

Chapter 1.

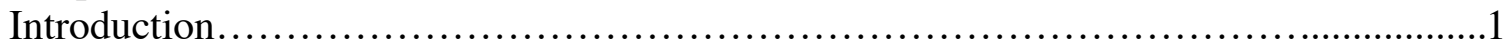

Statement of the Problem..........................................................................

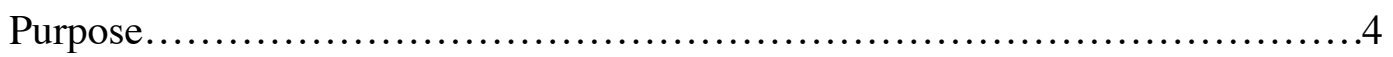

Research Questions.....................................................4

Significance......................................................4

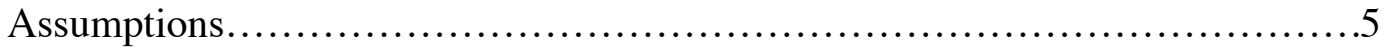

Delimitations.........................................................

Limitations........................................................5

Definitions...........................................................

Chapter 2.

Review of literature.....................................................

History.........................................................

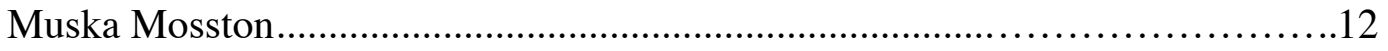

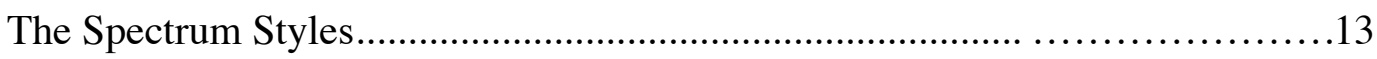

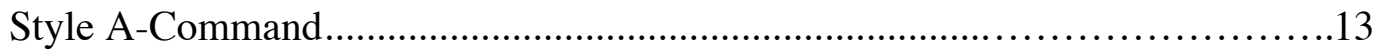

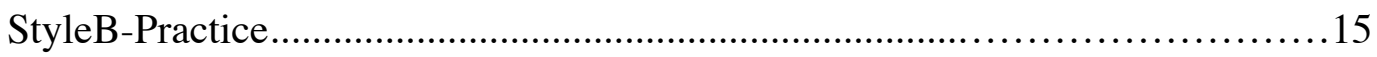

Style C-Reciprocal ................................................................. 16

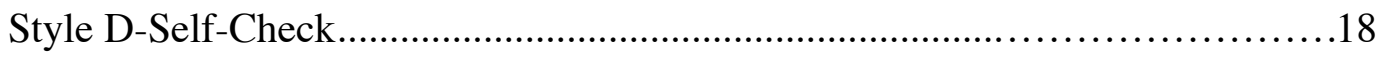

Style E-Inclusion...........................................................................

Discovery Threshold .....................................................................20

Style F-Guided Discovery .........................................................22 


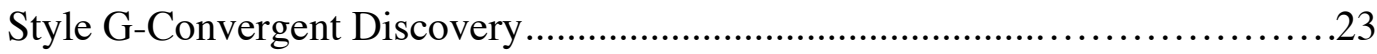

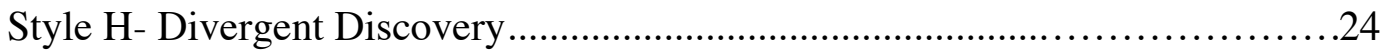

Style I-Learners Individualized Designed Program Style.......................26

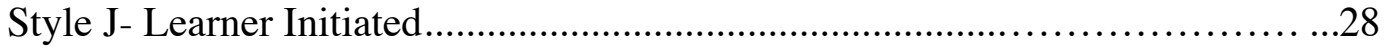

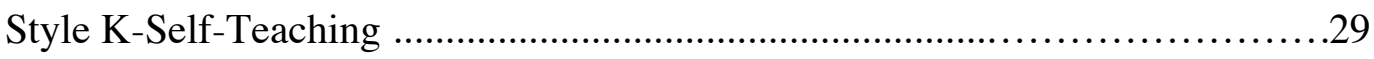

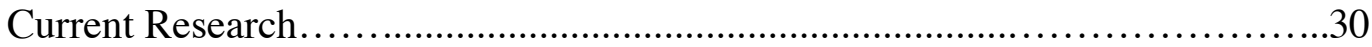

\section{Chapter 3.}

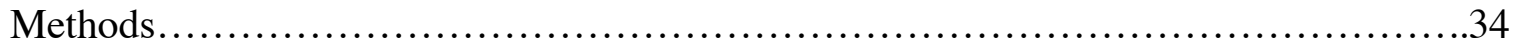

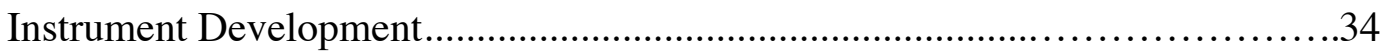

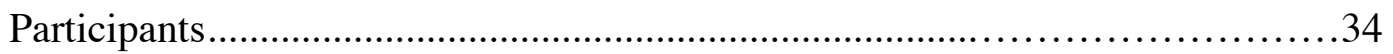

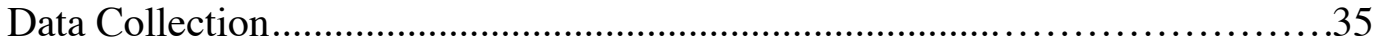

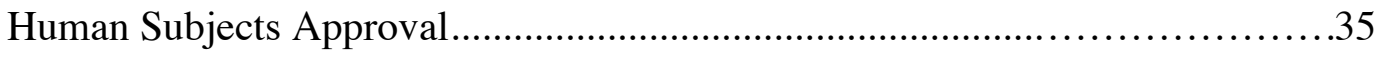

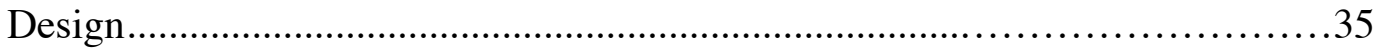

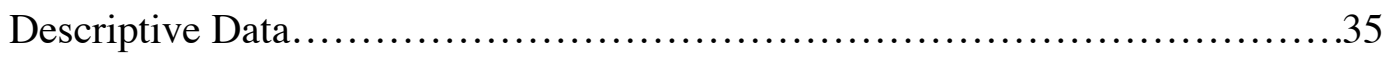

Chapter 4.

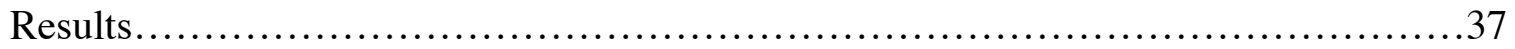

Teacher Demographics...................................................

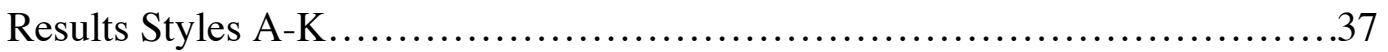

Chapter 5.

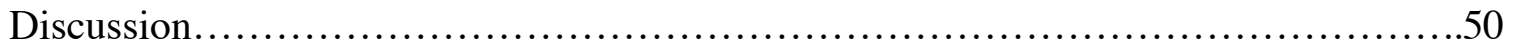

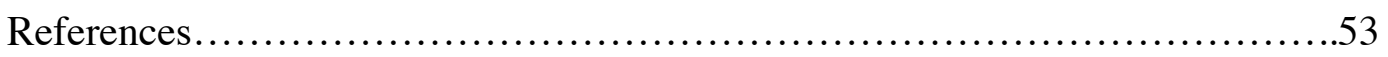

Appendix A-Letter........................................................ 55

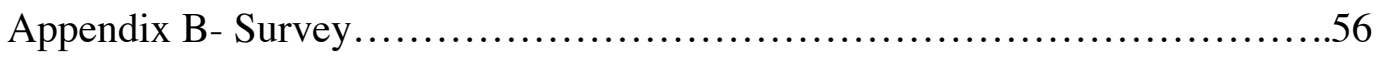


Appendix C- Overall Results...........................................65 


\section{LIST OF TABLES}

TABLE

Page

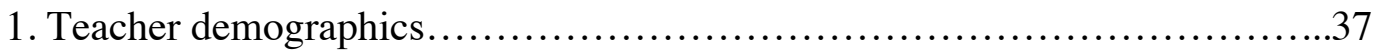

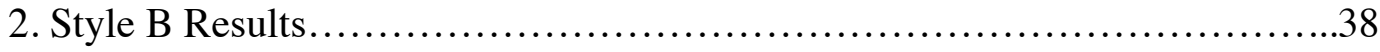

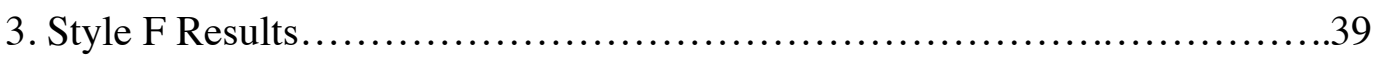

4. Style K Results...................................................... 40

5. Style C Results.....................................................41

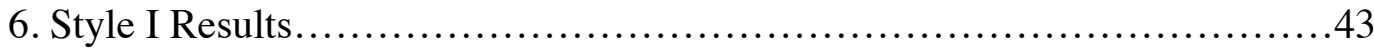

7. Style J Results......................................................43

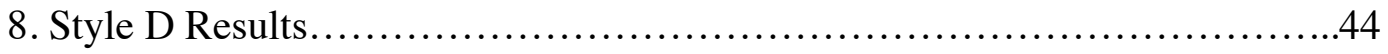

9. Style E Results.....................................................45

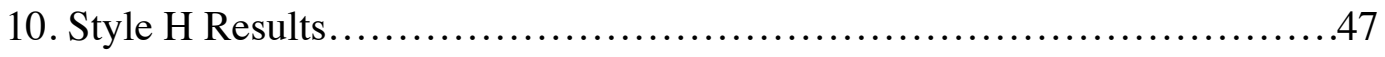

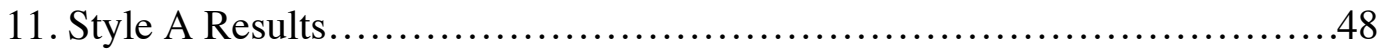

12. Style G Results.................................................... 49

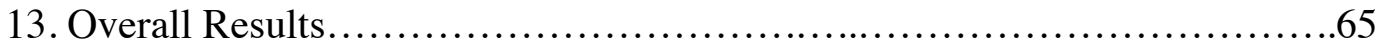




\section{CHAPTER 1}

\section{Introduction}

For a variety of reasons, teacher education has been under scrutiny during the past years (Byra, 2000). A few concerns include: what is the best way to teach; what training have teachers received; or what tools do teachers have to improve their teaching? One method frequently discussed and proposed for approaching the dilemma of which way is the "best way to teach" is the use of a range of teaching styles. Researchers suggest that when teachers use a variety of different teaching styles, they provide learners a wide range of options in which to gather knowledge (Byra, 2000). Using different approaches invites students to experience more content objectives, and to participate in a greater array of educational objectives (Kulinna \& Cothran, 2002). Additionally, it is suggested

that learning is enhanced through the use of a variety of teaching styles (Gerney \& Dort, 1992).

Gerney and Dort (1992) stated that perhaps the most comprehensive framework on alternative teaching approaches is The Spectrum of Teaching Styles. Gerney and Dort (1992) claimed, "No single book has been translated into more languages, been used by more teachers and teacher educators, and endured so long in our field." The Spectrum has been developed to address several factors affecting the teacher-learning relationship. Mosston's Spectrum delineates different teaching-learning styles and each style's influence on the diversity that exists among students and the vast array of objectives of the education. The reason for developing the Spectrum is to provide a comprehensive, integrated, and coherent theoretical framework on teaching (Mosston, 1992). Research shows that teachers who implemented Mosston's Styles gave more variety and specific 
feedback, changed teaching styles more frequently, and gave fewer negative statements (Ashworth, 1992).

The Spectrum of Teaching Styles is based on a decision making model that delineates for each style a Decision Anatomy, which consists of three sets of decisions: the PreImpact, the Impact, and the Post Impact Set. The Pre -Impact Set includes those decisions supporting the intent: the planning and preparation decisions such as setting the objectives, selection of the subject matter and the specific teaching approach (Mosston \& Ashworth, 2002). The focus of the Impact Set is the action and the actual face-to-face implementation of the Pre-Impact decisions. This set of decisions triggers the transaction, task engagement, or performance. The Post-Impact Set includes all the decisions associated with assessment-including feedback about performance and the overall evaluation of the teacher-learner experiences (Mosston \& Ashworth, 2002). The decisions within the three sets represent the Anatomy of Any Style. The various teaching styles (11 in total) were created by manipulating who makes which decisions about what, and when these decisions are made (Mosston \& Ashworth, 2002). A more recent development and classification not presumed previously is that the three sets do not refer to before, during, and after class (Mosston \& Ashworth, 2002). Time is not a factor that distinguishes the three sets because Pre-Impact, Impact, and Post-Impact decisions are necessary to define each individual style and each individual teaching episode. The teacher or learner makes decisions during each teaching-learning episode, therefore, defining the individual style (Mosston \& Ashworth, 2002). The three sets distinguish the purpose of the decision; planning, implementation, or assessment (Mosston \& Ashworth, 2002). Mosston and Ashworth, (2002) stated, "The Anatomy of Any Style, therefore, is a 
universal model that is the foundation of all teaching. It describes the decisions that must be made in any teacher-learner interaction, model, strategy, or educational game."

The Spectrum delineates a continuum of decision-making options from maximum decisions by the teacher to a gradual shifting of maximum decisions to the student (Cothran et al., 2003). The current version of the Spectrum (Mosston \& Ashworth, 2002) includes 11 different styles: Command, Practice, Reciprocal, Self-Check, Inclusion, Guided Discovery, Convergent Discovery, Divergent Discovery, Learner's Individualized Designed Program, Learner Initiated, and Self Teaching.

Many theoretical tools/questionnaires have been developed to identify teaching styles used by teachers. Most recently, Kulinna, Cothran, and Zhu, (2000) developed a questionnaire to identify physical educators' usage and perceptions of the 11 styles as described by Mosston and Ashworth (2002). The questionnaire is comprised of 11 scenarios describing the typical actions of a physical educator when using the different styles. Each scenario contains a description, followed by a series of questions related to the use and perception of the style. Teachers answer questions using a 5-point Likert Scale.

Currently, Mosston's Spectrum is being used in varying degrees within teacher preparation programs. Cothran et al., (2003) stated that there is a lack of research in Physical Education in regards to Mosston and Ashworth (2002), one of the most common models used in pedagogy in the international field of physical education.

Statement of the Problem.

Although tools have been developed to identify teaching styles and perceptions of styles used by teachers (Cothran, Kullina, \& Ward, 2000), limited research has been 
conducted for high school physical education teachers regarding their understanding and use of Mosston's Styles.

Purpose of the Study.

The purpose of this project is to determine if a tool can be created that lends insight into high school physical education teachers' understanding and use of Mosston's Styles of Teaching.

\section{Research Questions.}

In this project the researcher will begin a pilot study to develop a questionnaire that will answer the following questions. Can teachers recognize Mosston's Teaching Styles using the style descriptors provided in the questionnaire? Do the teachers perceive themselves using these styles? If yes, in what units do they use them? If no, what are their reasons for not using them?

\section{Significance.}

This project is significant because it lends insight into further perception and understanding of pedagogical knowledge by adding to the debate about the importance of teachers using different teaching styles to reach a wide range of learners. By lending information about whether or not teachers can identify the teaching styles, and if the teachers believe themselves as using them, in what units, and how often, it may give teacher preparation programs insight into the effectiveness of their programs. This knowledge may help assist teacher education programs in certain ways; showing the effectiveness of their teachers' use of a range of teaching strategies, and secondly, by gaining a better understanding of teachers' knowledge of styles. 


\section{Assumptions.}

It is assumed that all participants will answer each question honestly for each of the questions. It is further assumed that all participants will follow the directions and use the correct amount of time allotted to take the survey.

\section{Delimitations.}

This study is delimited to the three high schools in the Santa Barbara School District. This study is delimited to the six credentialed Physical Education teachers who were teaching physical education classes in one of the three high schools in the Santa Barbara School District at the time of this study.

\section{Limitations.}

A limitation to this study was the sample size of six respondents. Another limitation of this study was that all respondents were from Santa Barbara, CA.

\section{Definitions.}

1. Anatomy of Style: comprises the conceivable categories of decisions that must be made in any teaching-learning transaction (Mosston \& Ashworth, 2002).

2. Cognitive: Knowing, or apprehending by the understanding; as, cognitive power (Webster's, 1998).

3. Competence: The state or quality of being adequately or well qualified; ability; specific range of skill, knowledge, or ability (Webster's, 1998)

4. Criteria Sheet: determines the parameters for the observer' behaviors; it keeps the doer informed about the performance; it provides the teacher with a concrete basis for interacting with the observer (Mosston \& Ashworth, 2002) 
5. Framework: A set of assumptions, concepts, values, and practices that constitutes a way of viewing reality (Webster's, 1998).

6. Pre Impact Set: defines the intent-planning preparation decisions (Mosston \& Ashworth, 2002).

7. Impact Set: defines the action-the face-to-face implementation of the pre-impact decisions (Mosston \& Ashworth, 2002).

8. Logistics: management of the details of an operation (Webster's, 1998).

9. Post Impact Set: defines the assessment-including feedback about the performance during the impact, and overall evaluation of the congruence between the intent and the action of the learning experience (Mosston \& Ashworth, 2002).

10. Production styles: styles F-K; represents teaching options that invite production of new knowledge (Mosston \& Ashworth, 2002).

11. Reproduction styles: styles A-E; represent teaching options that foster reproduction using past knowledge (Mosston \& Ashworth, 2002)

12. The Spectrum delineates teaching-learning options. It equips teachers with the fundamental knowledge for developing a repertoire of professional behaviors that embrace all the objectives needed to connect with and to educate students (Mosston \& Ashworth, 2002)

13. Style A-Command Style: defining characteristic is precision performancereproducing a predicted response or performance on cue (Mosston \& Ashworth, 
2002).

14. Style B-Practice Style: defining characteristic is individual and private practice of a reproductive task with feedback (Mosston \& Ashworth, 2002).

15. Style C-Reciprocal Style: defining characteristics are social interactions, reciprocations, and giving feedback that is guided by specific criteria (Mosston \& Ashworth, 2002).

16. Style D-Self-Check Style: defining characteristics are performing a task and engaging in self-assessment (Mosston \& Ashworth, 2002).

17. Style E-Inclusion Style: defining characteristics are that learners with varying degrees of skill can participate in the same task by selecting the difficulty at which they can perform (Mosston \& Ashworth, 2002).

18. Discovery Threshold: invisible line between the reproduction cluster of styles A$\mathrm{E}$, and the production cluster of styles F-K; this line divides the behaviors that trigger memory, and those that evoke discovery (Mosston \& Ashworth, 2002).

19. Style F- Guided Discovery Style: defining characteristics is the logical and sequential design of questions that lead a person to discover a predetermined response (Mosston \& Ashworth, 2002).

20. Style G- Convergent Discovery Style: defining characteristics is to discover the correct (predetermined) response using the convergent process (Mosston \& Ashworth, 2002). 
21. Style H-Divergent Discovery Style: defining characteristics are to discover divergent (multiple) responses to a single question/situation, within a specific cognitive operation (Mosston \& Ashworth, 2002).

22. Style I - Learner Designed Individual Program Style: defining characteristic is the independence to discover a structure that resolves an issue or a problem (Mosston \& Ashworth, 2002).

23. Style J-Learner Initiated Style: defining characteristics are the learner's initiation of and responsibility for designing the learning experience (Mosston \& Ashworth, 2002).

24. Style K-Self- Teaching Style: defining characteristics are the individual tenacity and desire to learn (Mosston \& Ashworth, 2002).

25. Unified Theory of Teaching: pedagogy theory that takes into account the relationship among, and the integration of, all the teaching styles (Mosston \& Ashworth, 2002). 


\section{CHAPTER 2}

Review of Literature

The purpose of this project was to determine if a tool could be created that lends insight into high school physical education teachers' understanding and use of Mosston's Styles of Teaching. In this chapter the researcher examined the history of research in Physical Education, Muska Mosston and his Spectrum of Teaching Styles, and reported studies that examined teachers' and students' perceptions and use of Mosston's Styles of Teaching.

History.

Historically, researchers and teachers have examined teaching theories by asking questions concerning effective teaching techniques; therefore, it is important to examine the history of research in physical education. Rink (2002) explains that Physical Education research began around the 1940's by examining characteristics of teachers as it relates to teaching effectiveness. The research was predominantly fraught with methodological errors and based on scales that were not product oriented.

The focus of research during the 1950's and 1960's was on process-product studies, investigating room climate, and making assumptions about desirable process characteristics of instruction. These studies identified that the more the student talks in class, the more they learn. These studies attempted to identify what teachers do to produce more student talk. There was a large commitment to progressive education in terms of choosing variables for investigation such as student talk, use of student ideas, and teacher warmth. 
During the latter part of the 1970's, Rink (2002) explained the shift from processproduct to classroom management studies primarily studied by Kounin:

Kounin attempted to answer the question of what teachers do who are most effective in handling classroom management problems. Kounin did much to identify specific variables relative to classroom management and most of his work is maintained in the present literature as guidelines for teacher management. The behavior most strongly correlated with effective classroom management was withitness. Withitness is the ability of the teacher to know what is going on in the classroom and to target behavior accurately and with good timing. (1977, p.47)

Soar and Soar (1979) examined the relationship between teacher behavior patterns and teacher effectiveness. Their studies led to the development of good classroom management strategies and identified behaviors used by successful teachers.

Furthermore, Rink (2002) explained the more successful lines of research in history that seeks to connect what teachers do in the teaching process to what students learn. Roshenshine and Furst (1971) described this process-product research aimed to find relationships between variables describing the process of teaching, and the products or outcomes of the teaching. This research continued well to the early 1980's when a major breakthrough in the study of teacher behavior occurred where several well-financed large companies conducted studies of teacher effectiveness in the elementary school setting. These studies identified patterns of teacher behavior with variables that are situationspecific.

Costello (1977) identified through his research, academic learning time (ALT) as the amount of time a student has to practice the task. These studies found that the success 
rate of students increased with the amount of time (ALT) the students have to practice the task. A significant factor is the appropriate level of difficulty. Finding an appropriate level of difficulty will increase the chance of the student's success. These studies led researchers into the next area of research-direct instruction. Research defines direct instruction as:

1. A task-oriented but relaxed environment.

2. Selection of clear instructional goals and materials and a highly active monitoring of students' progress towards these goals.

3. Structured learning activities.

4. Immediate, academically oriented feedback.

After examining feedback and its appropriateness, Tobey (1974) found that teachers use both praise and criticism during teaching. His studies showed that praise should be used with honesty and credibility for each individual student to motivate them internally. Criticisms with negative feedback should be avoided.

Tobey (1974) examined feedback and its appropriateness. Tobey found that teachers use both praise and criticism during teaching. His studies showed that criticisms with a negative effect should be avoided, and that praise should be used with guidelines such as honesty and credibility, for each individual student, for internal motivation. Rink (2002), acknowledged direct instruction as a blueprint for effective teaching in past years, but also believed that other research may identify better teaching strategies that take into consideration different subject matter, students, and goals - in other words, not wanting to abandon research on what effective teachers are doing just because researchers have their mind set on one specific philosophy. Understanding the perspectives of all the 
participants in the teaching learning process may give answers to questions about their experiences and how they perceive those experiences. For these types of questions naturalistic inquiry or qualitative research has been used extensively.

\section{Muska Mosston.}

Muska Mosston (1925-1994) taught physical eEducation in several places in his native Israel before leaving for the United States in 1950 to earn a Bachelor's of Science, and Master's in Education at the City College of New York. His early professional experiences included teaching at Rutgers University, East Stroudsburg University, and Temple University. He also earned an Honorary Doctoral Degree from the University of Jyvaskyla in Finland. He served as chairperson of the Kinesiology Department at Rutgers University and later in his career earned a doctorate at Temple University (Mueller and Mueller, 1992). The Spectrum of Teaching Styles (Mosston \& Ashworth, 2002) describe Muska Mosston as a man who loved teaching physical education to all different levels of learners. When he saw students not given the opportunity to move and learn, it outraged him. This led Muska Mosston to start observing students, from top athletes to the most disabled, to identify their strengths and weaknesses. It was his plan to create a spectrum of developmental opportunities for them to discover new ways to rejoice in the process of learning. He could not think in haphazard or random fashion, which led him to think about fundamental and universal teaching concepts, leading to his most notable work in the early 1960's (Mosston \& Ashworth, 2002). In 1964 Muska Mosston's produced his most prominent work, The Spectrum of Teaching Styles, which has influenced physical education for the past 38 years. The Spectrum continues to be used in several university teacher education programs worldwide (Gerney \& Dort, 1992). 


\section{The Spectrum Styles.}

In this section, the styles discussed were based on Mosston and Ashworth's latest edition of Teaching Physical Education by Muska Mosston and Sara Ashworth (2002). Descriptions of Styles A-E will be discussed first, followed by an explanation of the Discovery Threshold, then descriptions of Styles F-K. Styles A-E are designed for the acquisition of basic skills, the replication of models and procedures, and the maintenance of cultural traditions (Mosston \& Ashworth, 2002). Styles A-E represent teaching styles that foster reproduction of subject matter (Mosston \& Ashworth, 2002).

\section{Command Style- A.}

Mosston and Ashworth (2002) discuss the defining characteristics of Style A. As discussed previously, the differences among the specific styles are created by shifting who makes the various decisions and when. In any teaching-learning relationship there are two decision makers: teacher and learner. Each decision maker is able to make maximum or minimum decisions as outlined in the anatomy of the style. This minimummaximum continuum in decision-making defines the limits that can be applied to the anatomy of each style.

Precision performance reproducing a predicted response or performance on cue is the defining characteristic of The Command Style. The teacher's role is to make all decisions, and the learner's role is to follow these decisions on cue. In Style A - The Command Style, the teacher makes all the decision in the Pre-Impact Set, Impact Set, and Post-Impact Set. In other later styles, the learner actually makes decisions. In The Command Style, the learner either makes the choice of "Yes, I'll do it" or "No, I will not do it." The style is direct with an immediate relationship between the teacher's stimuli 
and the learner's response.

The defining characteristic of The Command Style is precision performance-reproducing a predicted response or performance on cue. The teacher is in charge of the learning experience, including breaking all the skills into parts and demonstrating the content and the procedures for performing the skill. Students are expected to move when (on cue) and exactly as the teacher performed the task, like a crew team or conductor or a marching band. The students copy the teacher's exact model and the teacher provides the feedback. This teaching approach can be very useful in certain lessons where precision performance, cultural traditions, or safety issues need to be maintained. For example, the Command Style could be effective in safety and high-risk courses like archery or gymnastics. A beginning mountain climbing class is another Command Style opportunity where high-risk and life-threatening consequences could occur if exact instructions were not followed. When using the Command Style, a person must be aware not to abuse the decision making power in a controlling matter.

The teacher must be aware of the emotional context of this behavior. There are at least two possibilities that can develop. One is the abuse of the power by the teacher, who may use this behavior for control and reprimand purposes. (When we reprimand someone, we usually take away decisions.) When this type of teaching behavior prevails, negative feelings often result and the learner will reject the teaching style, the teacher, and the subject matter. The second possibility is that the teacher will use the Command Style with affection, charm, and care. The Command Style does not mean, "being mean"; this behavior can be used to motivate learners, elevate self-concept, and develop esprit de corps. 
(2002, p. 88)

Practice Style-B.

Practice Style B decision anatomy is different than the Command Style; therefore, the content learning outcomes, the effect on the diverse population, and the educational objectives that are emphasized are also different. This Style is beneficial for students learning to develop an initial degree of physical education because it may help build independence and confidence by working alone.

The following statements offer an image of the Practice Style according to Mosston and Ashworth, (2002).

The characteristic of Practice Style B is individual and private practice of a memory/reproductive task with feedback. In the anatomy of the Practice Style the role of the teacher is to make all subject matter and logistical decisions and to provide feedback to the learners. The role of the learner is to individually and privately practice a memory/reproduction task ... (p. 94). Perhaps the most accurate name for this landmark decision relationship is Individual Practice style. Despite the variety of names that could be used to describe this behavior, it is vital to focus on the distribution of decisions that determine the learning objectives. (p. 96)

The design of Style B is set up so that learners individually practice a specific task while making specific decisions on their own. The anatomy of the Practice Style differs slightly from the Command Style. In the Pre and Post Impact Sets, the teacher continues to make all the decisions, but in the Impact Set in the Practice Style, nine impact decisions (location, order of tasks, starting time, pace and rhythm, stopping time, interval, 
initiation of questions, attire, and posture) are shifted from the teacher to the learner (Mosston \& Ashworth, 2002). In this style, and in all additional styles, the teacher must understand the deliberate shift of decisions to be made in the specific style's Anatomy and find tasks that are conducive to the style. In the Practice Style-B during the Impact Set, it is the role of the learner to work individually and privately and to provide the teacher with time to offer the learner individual and private feedback, in addition when the teacher is offering private or public feedback then post impact is occurring during the face-to-face time with the student. Once the teacher has offered feedback to the class, decisions will be made about the content and style for the following episodes. The Practice Style invites the learners to make decisions that permit them to work privately and individually; consequentially, communication among or between students must be kept to a minimum.

Moving further along the Spectrum, other styles and how they could be a rewarding and character building experience for students are examined. The authors suggest that Style C leads to allowing learners more decisions and opportunities to develop human attributes that emphasize significantly different learning objectives, leading to increased responsibility and independence.

\section{Reciprocal Style- $C$.}

In the next Style the researcher will examine how the decision structure changes to introduce a new learning experience for learners. The Reciprocal Style's decision structure is set up so that the learner will have the opportunity to experience social interaction, reciprocation, and provide guided feedback. Mosston and Ashworth, (2002) explain the decision structure of the Reciprocal Style-C: 
The defining characteristics of the Reciprocal Style are social interactions, reciprocations, and giving feedback (guided by specific criteria). In the anatomy of the Reciprocal Style, the role of the teacher is to make all subject matter, criteria, and logistical decisions and to provide feedback to the observer. The role of the learners is to work in partnership relationships. One learner is the doer who performs the task, making the nine decisions of the Practice Style, while the other learner is the observer who offers immediate and ongoing feedback to the doer, using a criteria sheet designed by the teacher. At the end of the first practice, the doer and observer switch roles-hence the name for this landmark behavior-the Reciprocal Style. (p.123)

The new objectives in this landmark behavior emphasize two dimensions-social relationships between peers, and conditions for immediate feedback. The anatomy of the Reciprocal Style has the teacher making all the decisions in the Pre-Impact Set. The doer is making the nine decisions in the pre-impact set; the shift of decision-making takes place in the post-impact set, when the observer makes the feedback decisions. The teacher does not communicate with the doer to avoid usurping the observer's role.

In the Impact set the teacher can delegate roles to one pair of learners or the learners can decide who their partners will be. One learner will perform the task, and the other becomes an observer providing feedback. Once the first practice-feedback session has occurred, the learners will switch roles. During the Impact Set, the teacher circulates and communicates with the learner/observer. No communication should be made between the teacher and the learner/doer so the doer can focus on making the nine impact decisions outlined previously in the Practice Style and the learner/observer role will be reinforced 
as the one to give feedback to the doer (Mosston \& Ashworth, 2002). In the Post Impact Set, the teacher can give closure or feedback to the entire class, and also refer to the learners/observers' role in the discussion.

The Reciprocal Style continues the developmental process for both the teacher and the learner. This behavior provides the learner with the opportunity to make post-Impact decisions, which creates a new reality in the teacher/learner relationship.... It is also a new reality for the teacher who has learned to shift the Post-Impact decisions - a source of power-to the developing learners. The next teaching-learning behavior requires an additional shift in the decisions so that new objectives and a different emphasis on the developmental channels can be identified. (p. 137)

\section{Self-Check Style-D.}

Each time teachers move from one style to another along the Spectrum there is a shift in the decision making structure. This shift permits an opportunity for the teacher to create new learning objectives and give our diverse student population more opportunities to grow as individuals. The authors describe the decision making structure of the Self-Check Style:

The defining characteristics of the Self-Check Style are performing tasks engaging in self-assessment. In the anatomy of the Self-Check Style, the role of the teacher is to make all subject matter, criteria, and logistical decisions. The role of the learner is to work independently and to check his or her own performances against criteria prepared by the teacher. When this behavior is achieved, objectives related to subject matter and behavior can be reached. (p 141) 
The Self-Check decisions shift to the learner in the Impact and Post-Impact Sets. This style provides opportunities to teach the learners to be competence in individual practice of the tasks (the nine impact decisions of practice style) and self-comparing, contrasting, and drawing conclusions about their individual performance (the Post-Impact decisions of the Reciprocal Style). The authors state, "The decisions of the Self-Check style lead learners to the next behavior-one that shifts even more decisions and responsibility to learners" (p. 151).

\section{Inclusion Style-E.}

The decision structure of the Inclusion Style offers opportunities for learners to perform at different levels of difficulty by designing different degrees of difficulty for a skill. Learners can participate in the same task by selecting a degree of difficulty at the level they can perform (Mosston \& Ashworth, 2002). The "Slanted Rope" scenario best explains the concept of inclusion. Mosston and Ashworth (2002) present the following scenario to introduce and illustrate the inclusion concept:

Holding a level rope about one foot above the ground we asked students to jump over one-by-one. When all had cleared the rope we asked: ("What shall we do with the rope now?") Instantly the answer came forth: ("Raise it!") We raised the rope a few more inches and continued to raise the rope each time and the students continued to jump over it. When the rope reached a given height, the inevitable happened. Some students could not clear the rope; they walked away and sat down. As we continued raising it, more students failed to clear the rope until there was none. "This experience" we said, "expresses the concept of exclusion-the single standard design of the task." We then asked, "What can be done with the 
rope to create a condition for inclusion - for all learners to be successful in going over the rope? After a moment of silence, all students were immersed in thought. "I know," announced on student, "let's slant the rope." We raised one end of the rope to chest level, and the other end on the ground. All students were able to participate at various levels. "This experience," we said, "expresses the concept of Inclusion." (p. 157)

The Anatomy of the Inclusion Style reinforces the decision structure of the SelfCheck Style. The additional emphasis is that the teacher in the Pre-Impact Set focuses on the preparation of the task and the levels within the task, the criteria sheet and clue comments to guide the students' understanding of the task. The two additional decisions in the Impact and Post-Impact Sets include selecting the appropriate level for their perceived ability, and two, asking the teacher for clarification while checking their own work against the teacher prepared criteria. The Inclusion Style gives students the opportunity to gain more experience in the decision-making process.

\section{The Discovery Threshold.}

Mosston and Ashworth, (2002) explain that Styles A-E gradually move from reproduction behaviors to Styles F-K production behaviors. Between these two clusters of styles is the Discovery Threshold, an imaginary line that denotes memory from discovery teaching and learning:

The cluster of styles A-E serves the human capacity for reproduction (memory) and the cluster of styles F-K serve the human capacity for production (discovery). Between the cluster of behaviors that trigger memory and those that evoke discovery, there is a theoretical, invisible line called the Discovery Threshold. 
(p.55)

The Discovery Threshold is a term used to designate an imaginary line that distinguishes one cluster of teaching styles from another along the Spectrum. This demarcation serves as a barrier between styles that invite the student to engage in reproduction tasks, and those tasks that invite production. Mosston and Ashworth (2002) eloquently discuss the crossing of the Discovery Threshold:

When the intent of an episode shifts to discovery (styles F-K), both teachers and learners must cross the Discovery Threshold by changing their behaviors. The teaching-learning behaviors shift when the teacher introduces different stimuli/questions that move learners across the threshold and engage them in the discovery process. The learners' behavior shifts to active production in discovering- by designing movements, by sequencing information, and by actively discovering the intended cognitive operation." (p. 55)

Teachers must take into consideration that many words can trigger cognition (Mosston \& Ashworth, 2002). Knowing which words to use will permit teachers to construct questions leading to the intended subject matter goals. Examples of some words to use in the memory (reproduction) cluster could be: label, copy, match, compare, contrast, sort, etc. Likewise, words used in the discovery (reproduction) cluster could be: design, hypothesize, imagine, compose, create, etc. (Mosston \& Ashworth, 2002). Crossing over the Discovery Threshold will examine the Styles F-K, the discovery (production) cluster, and the other end of the Spectrum. The experiences learners will gain from styles on the production side of the Discovery Threshold might help students take content responsibility for themselves during their learning process. 


\section{Guided Discovery Style-F.}

A goal of teaching is to provide students with opportunities to become self-sufficient in all areas of their life. This includes being a productive member of society, and having the ability to act, learn, and make decisions on his or her own. Style F allows the learner the ability to engage in the first behavior of discovery, Guided Discovery. Mosston and Ashworth (2002) describe the decision structure of the Style-F, the first style presented after crossing the Discovery Threshold:

In the decision structure of The Guided Discovery Style-F, the teacher must design a logical and sequential design of questions that lead a person to discover a predetermined response. In the Anatomy of the Guided Discovery Style the role of the teacher is to make all subject matter decisions, including the target concept to be discovered by the student, and the sequential design of questions for the learner. The role of the learner is to discover answers. This implies that the learner makes decisions about segments of the subject matter within the topic selected by the teacher. (p. 212)

In regards to the Anatomy of the Guided Discovery Style, Mosston and Ashworth (2002), state:

In this behavior the teacher makes all the decisions in the Pre-Impact Set. This includes decisions about the objectives, the subject matter concept target, the design of the logical sequence of questions that will guide the learners to discovery of the target, and all logistical decisions. More decisions than previous are shifted to the learner in the Impact set. The act of discovering the answer means that the learner makes decisions about elements of the subject matter 
within the topic selected by the teacher. In the Post-Impact Set, the teacher (or surrogate) verifies the learner's response to each question/clue. In certain situations the student may be able to verify the responses by him/herself. This role of continuous, correspondence between the teacher and learner in both the Impact, and Post-Impact Sets are unique to this style. (p. 213)

To review, an important aspect of this style is that the teacher must be responsible for the precise design of questions that will lead to a correct response, while also trusting the cognitive ability of the students to discover the learning objectives of the selected subject (Mosston \& Ashworth, 2002).

\section{Convergent Discovery Style-G.}

The Convergent Discovery Style is similar to the previous Style (Guided Discovery). Again changing the structure of the decision making will allow the teacher to change objectives in the lesson, and delegate more learning authority to the learner and give the learner more opportunity to work independently and productively. Mosston and Ashworth (2002) describe the decision structure for the Convergent Discovery Style: The defining characteristic of the Convergent Discovery Style is to discover the correct response using the convergent process. In the anatomy of the Convergent Discovery Style, the role of the teacher is to make subject matter decisions, including the target objective to be discovered, and the single question delivered to the student. The role of the learner is to engage in reasoning, questioning, and logic to sequentially make connections about the content to discover the answers (p.237). In the previous behavior (Guided Discovery) the teacher prepared the questions and arranged the tightly woven sequence that led to the anticipated 
response. But now, in Convergent Discovery, the learner produces the questions and arranges the logical sequence that ultimately leads to discovery of the anticipated response. Although learners may use different approaches to solve the problem, they will each converge on the same response using rules of logic and reasoning, (p.238) In the Impact Set, after presenting the problem(s) to the learner(s), the role of the teacher is to observe the learners as they move through the discovery process. This role requires patience, because the there is a tendency for teachers to jump in and intervene. It is imperative for the teacher to wait. Discovery thinking takes time. The learners need time to evolve ideas, examine them, sift through ideas, and decide on the appropriate solution. This process is a very private one-don't intervene! (p.238). In the Post-Impact Set, the teacher may participate by asking questions to verify the solution, after the student has spent time in inquiry, in trial and error, and examining the solution. (p.239).

\section{The Divergent Discovery Style- $H$.}

The Divergent Discovery Style invites learners to discover different solutions to the same problem. Problem solving takes place in all aspects of life. Finding different solutions to problems will give learners a valuable skill to take with them through life. Mosston and Ashworth (2002) describe how the decision making structure changes in Style-H:

The defining characteristic of the Divergent Discovery Style is to discover divergent (multiple) responses to a single question/situation, within a specific cognitive operation, in the Anatomy of the Divergent Discovery Style, the role of the teacher is to make decisions about subject matter topic, and specific questions 
and logistics to be delivered to the learner. The role of the learner is to discover multiple designs/solutions/responses to a specific question. (p. 247)

Using this behavior the teacher's intentions are to activate divergent thinking in the specific cognitive operations designated by the stimuli provided (Mosston \& Ashworth, 2002).

Furthermore, Mosston and Ashworth (2002) go into the Pre-Impact, Impact, and Post-Impact Sets in the anatomy of Style-H. In the anatomy of the Divergent Discovery Style the teacher makes all decisions in the Pre-Impact Set about subject matter, and supply specific questions and logistics to the learner. All decisions in the Impact set then shift to the learner who makes the decisions about movement designs, problem solving methods, and ideas. There are multiple ways for the teacher to ask the questions to lead to the overall objective (s). The teacher can give the student one single task/question, or a series of tasks or themes to explore. Likewise, the students will be invited to discover alternative designs and responses within the content. In the Post-Impact Set, the teacher must serve as a source of verification to the learner, and the learner must seek validity of his/her responses. Therefore they both have a part in the decision making process in the Post-Impact Set:

Divergent Discovery Style is an open-ended process in two avenues. First, the subject matter itself is open-ended because there is always a possibility of another solution, movement, way to pass a ball, or break through the opponent's defense. Thus the subject matter becomes dynamic; it is constantly renewed. Second, the process of discovery is self-perpetuating. The act of finding a new solution validates the process of discovery. The joy of discovery is so powerful that the act 
of discovery itself becomes the reinforcing, motivating agent that propels the students to seek more solutions, alternatives, and ideas. (p. 273)

The Divergent Discovery Style shifts learners to the role of creator. It allows them to use inspiration to produce ideas in the focus area presented by the teacher. The next landmark style shifts to the learners more independence on the road to developing both cognitively and physically (Mosston \& Ashworth, 2002).

Learners Individual Designed Program Style -I.

In the last three styles the learner had the opportunity to discover answers based on ideas presented by the teacher. The structure of the Learner Individual Designed Program Style is the independence to discover a structure that resolves an issue or problem. Specifically, in Style F-Guided Discovery the learner's response depends on careful sequence of stimuli presented by the teacher (Mosston \& Ashworth, 2002). Earlier, Style G-Convergent Discovery calls on the learner to have greater independence and discover the one correct answer without clues or guiding questions by the teacher (Mosston \& Ashworth, 2002). The content help received by the learner from the teacher slowly decreases allowing more independence. Again, in Divergent Discovery Style H the same occurs. In Style H, the student is provided the opportunity to produce multiple solutions/movements/responses to a given problem. In all these three discovery styles, the teacher/learner bond is still very strong, with the teacher designing the subject matter, and the questions or problems for the Impact Set. Mosston and Ashworth (2002) describe the changes that occur in the Learners Individual Designed Program:

In the Learners-Designed I. P. (Individual Program) Style-I, the learner's independence becomes even more pronounced because the teacher designates 
only the subject matter area .... Within that subject matter area, the learner discovers and designs the questions or problems and seeks the solutions. Unlike all previous styles /behaviors (A-H), the objectives of the Learner-Designed I.P. Style cannot be accomplished in one episode or one classroom period. A series of episodes over a period of time, including both reproduction and production experiences, structured by the individual learner, are necessary to accomplish the objectives of the Individual Program Style. (p. 275)

The Anatomy of the Learner Designed Individualized Program is different from any other style. The students learn to produce an individual learning program that compliments the topic and makes supporting decisions related to the learning process, while the teacher's role is to provide parameters to the learners (Mosston \& Ashworth, 2002). The teacher presents the expectation decisions and decides ways to invite the learners to participate in this new degree of independence (Mosston \& Ashworth, 2002). Additionally, the teacher provides the learners with a general subject matter area in which they will evolve their own questions and answers and produce their individual program (Mosston \& Ashworth, 2002). During the Impact Set, the learner must work on five different criteria. First, the learner must select what topic he/she will focus on. Secondly, the learner must identify questions and issues appropriate for that topic. Third, the learner must organize the questions, sequence the tasks, and design a personal program or course of action. The fourth task is to collect data about the topic, to answer the questions, and organize the answers into a reasonable framework. Finally, the fifth task of the learner is to verify the procedures and solutions based on criteria related to the subject matter at hand. The role of the teacher in the Impact Set is to observe the learners' progress and 
listen to the learners' questions and answers. In the Post-Impact Set the learner is to verify the procedures and communicate those results to the teacher. The teacher's role in the Post-Impact set should be to be available for questions, listening and asking questions, and offering feedback to the learner about their content and decision-making process (Mosston \& Ashworth, 2002). The next style shifts even more decisions to the learner.

Learner-Initiated Style-J.

In the Learner Initiated Style the learner is allowed for the first time to make PreImpact decisions. The decision structure of the Learner Initiated Style is that the learners' role changes, specifically in the Pre-Impact Set. Mosston and Ashworth examine the decision structure of Style-J:

The defining characteristic of the Learner-Initiated Style is the learner's initiation of, and responsibility for designing, the learning experience. In the anatomy of the Learner-Initiated Style, the role of the learner is to independently initiate this behavior and make all decisions in the Pre-Impact, including which teachinglearning behaviors will be used in the Impact, and create the criteria decisions for the Post-Impact. Provided the teacher is qualified in the subject matter, the teacher's role is now to accept the learner's readiness to make maximum decisions in the learning experience, to be supportive, and to participate according to the learner's requests. (p. 283)

The primary objective of this style is to honor the learners' need to be independent, and give the student the opportunity to challenge him or herself. This style can give students the opportunity to explore and foster their own interests (all styles challenge 
learners). The learner will have opportunities to create his/her own learning experience and maybe even explore subjects not presented in class. Mosston and Ashworth (2002) explain that the more experience the learner has in the previous styles, the more experienced they will be to incorporate other landmark styles in their own investigation.

The Self-Teaching Style is the last landmark style on the Spectrum. The next section will examine how it differs from the Learner Initiated Style.

Self-Teaching Style-K.

Mosston and Ashworth, (2002) insist:

The Self-Teaching Style does not exist in the classroom. The decision structure of the Self-Teaching Style acknowledges the tenacity and desire of individuals to learn. In the anatomy of the Self-Teaching Style, the individual participated in the roles of both the teacher and the learner and makes all decisions - in the Pre-Impact, Impact, and Post-Impact Sets. When this behavior is achieved, the objectives that the individual has established in subject matter and in behavior are achieved. This behavior does not have a precise designated set of objectives: the individual selects objectives, (p.290). Who is the self-teaching individual? It can be anyone who fathoms the intricacies of a complex hobby, an individual who is fascinated and driven to know something, or the scientist who is propelled to understand the unknown... (p.290) Leonardo da Vinci is a well-known example of an individual who lived most of his life anchored in the SelfTeaching Style. Not all individuals who are involved in Self-Teaching Style are "da Vinci's," but they do, in varying degrees, share the 
characteristics of curiosity, wonder and the tenacity to endure a process of discovery" (p. 290). The ability to engage in Self-Teaching may seem to be the ultimate in human development. Certainly, in education, it has been perceived at time as the apex of development, the stage when one becomes a truly free person (p. 291). As we saw in the beginning of the Spectrum, when Style A is used exclusively, there is a limit to the goals that can be met. With all of its assets, the decision structure of the Command Style represents only a portion of human behavior. Similarly, the Self-Teaching Style, despite its assets, has limitations when it stands alone. (p. 291)

These teaching styles and the structure of decision making to reach pre-determined objectives can help us reach the diverse population of our students. Given these tools provided, teachers can create experiences to give all of the diverse learners positive learning experiences that help them function in life. Mosston and Ashworth (2002) discuss the Unified Theory of teaching:

Therefore a Unified Theory of teaching must take into account the relationships among, and the integration, of all the styles. It is the full Spectrum of Styles, not a particular style used in isolation-that will serve as a cornerstone for an expanded pedagogy. (p. 292)

\section{Current research.}

Cothran, Kullina, and Ward (2000) investigated students' experiences and their perceptions of Mosston's Teaching Styles. The main focus of their study was to see if students had experienced the full spectrum of teaching styles. Also, they asked, could the students differentiate among the educational strategies of the different teaching styles? 
The first task in this research project was to develop a tool to use to examine the students perceptions. A short descriptive scenario was written for each of the 11 teaching styles in the Spectrum (Cothran et al., 2000). A content validity of the test was performed with a panel of five physical education pedagogy experts. All five experts were familiar with Mosston's Spectrum (Cothran et al., 2000). They were asked to provide comments about the appropriateness of the scenarios, and all panel members gave $100 \%$ agreement that the scenarios reflected the teaching styles they were designed to represent (Cothran et al., 2000). The styles were then put in a survey instrument. The instrument had a scenario followed by four statements: (a) I had a physical education teacher teach this way; (b) I think this way of teaching would make the class fun; (c) I think this way of teaching would help students learn skills and concepts; (d) I think this way of teaching would motivate students to learn (Cothran et al, 2000). A 5-point Likert-like scale was used to rate "never" to "always" for the first statement, followed by "strongly disagree" to "strongly agree" (Cothran et al., 2000). Questions about a student's age, ethnicity, and self-perceived ability in physical education were also asked. A pilot test was conducted with a group of students enrolled in a physical education class (Cothran et al., 2000). The students were asked to circle any words or descriptions that were unclear or confusing (Cothran et al., 2000). Since the physical education class, or the panel of experts recommended no changes, the final version was created with three different versions to account for potential order bias. The tool was then administered to 438 college students enrolled in physical education elective courses at a large university. Findings suggested that students had more experience with the reproduction styles and that they differed in their perceptions of the value of the 11 teaching styles. Understanding this data is crucial 
to the development/implementation of pedagogy. When training in-service teachers, research suggests that learning is not reproduction, but constructive (Cothran et al., 2000).

Kulinna, Cothran, and Zhu (2000) presented a paper at the annual meeting of the American Education Research Association in New Orleans, Louisiana. They examined teachers' experiences and Perceptions of Mosston's Spectrum, and how they compared with students. Understanding teachers' experiences and perceptions of Mosston's was significant because of the Spectrum's central role in physical education pedagogy (Kulinna et al., 2000). Furthermore, (Kulinna et al., 2000) state that comparing teachers' and students' perceptions will lead to an increased understanding of how teaching styles affect the teaching-learning process, and hopefully help bridge the gap between teachers' and students' perspectives (Kulinna et al., 2000). An instrument was also modified and validated in order to assess teachers' experiences and perceptions of teaching styles (Kulinna et al., 2000). The original instrument was developed by Cothran et al., in 2000, in his article entitled, "Students' Experiences and Perceptions of Teaching Styles." The wording of the instrument in Kulinna's study was modified to collect a teacher's point of view. Participants for the Kulinna study were 212 physical education teachers from Indiana and Michigan. Opinions were collected to examine if the "Teachers' Perception of Teaching Styles" instrument could produce valid and reliable scores within the selected population (Kulinna et al., 2000).

This data collection instrument underwent another revision for the next study. Kullina and Cothran (2002) examined teachers' self reported use of Mosston's' teaching styles, and perceptions of their self-rated teaching ability in relation to using the styles. The 
instrument produced reliable and valid scores for the student participants in the original validation study (Kullina \& Cothran, 2002). The reliabilities of the scores were estimated by assessing internal consistency among the questions. The reliability assessments show a high level of inter-item agreement among items for each style with Cronbach alpha coefficients ranging from .86 to .91 . Construct validity was measured using an exploratory factor analysis. The analysis extracted 11 factors with perfect correspondence to the 11 teaching style scenarios. In addition, each teaching style was a factor identified in the analysis. The validation process included a pilot study, content review by an expert panel, and a reliability and validity study with 438 college students. 


\section{CHAPTER 3}

Methods

Instrument development.

For the instrument used in this study, descriptive scenarios were modified using the established questionnaire of students' experiences and perceptions of teaching styles they experienced (Cothran, Kulinna \& Ward, 2000). These scenarios were further modified and updated using the teaching styles of Mosston \& Ashworth (2002), in consultation with Dr. Ashworth, a teaching expert who co-authored Teaching Physical Education by Mosston and Ashworth (2002). Through e-mail and telephone correspondence, Dr. Ashworth helped this researcher update the previous questionnaire to ensure the P.E. classroom examples correctly reflected each teaching strategy. These scenarios and examples were then put into the teacher survey. The teacher survey recorded both the example and a question asking for in what unit, and how many lessons, the teachers used this style in each unit.

\section{See (Appendix B)}

\section{Participants.}

Participants in this study were from three different central coast high schools in the Santa Barbara Unified School District. The participants were six teachers credentialed in physical education, and currently working at one of the three schools in the district. Subjects were three Caucasian males, two Caucasian females, and one Hispanic female. All subjects age ranged from 35-45 years old, and all had formal teaching training in physical education. Subjects had at least five years teaching experience. Subjects consisted of one male and one female from each of the three high schools. 


\section{Data collection.}

After the district office, school administrator, and physical education department granted permission, two teachers from each school—one from the men's physical education department and one from the women's physical education department - were recruited to volunteer. The teachers were given approximately thirty minutes to complete the survey. The respondents' identities were kept anonymous, and the respondents took no more than the allotted time to complete the surveys.

\section{Human Subjects Approval.}

According to the Human Subjects Approval Committee at California Polytechnic State University, this project and surveys were approved prior to data collection.

Design.

This project was designed as a descriptive pilot study to examine the use of the current instrument to collect opinions from teachers. The six teachers completed the survey about their knowledge of Mosston's Spectrum. These data were then examined to determine whether teachers could recognize the styles using the descriptor provided in the questionnaire. Also the data was examined to see if teachers used the styles. If so, they were asked in what units they used the styles. If they did not use the styles, they were asked to give their reasons for not using certain styles of teaching.

\section{Descriptive data.}

Due to the limited number of respondents, the researcher examined the data using a descriptive statistical approach. Specifically the data was to examine the teachers' ability to recognize the style described correctly, and then determine which units (if any) 
they used that style, and then collect any details about how the lessons ran per unit. 


\section{CHAPTER 4}

Results

This section describes the results of the survey beginning with the respondent's demographics (see table 1). Each question from the survey is written out here, followed by the resultant findings from the survey. A table displaying each reply is depicted first, followed by an explanation of the findings.

Table 1

Demographics of Teachers'

\begin{tabular}{llllcc} 
Teachers & M/F & Ethnicity & Age & PE Credential & 5+ yrs \\
\hline 1 & M & Caucasian & 45 & y & y \\
2 & M & Caucasian & 49 & $y$ & y \\
3 & M & Caucasian & 43 & y & y \\
4 & F & Caucasian & 38 & y & y \\
5 & F & Caucasian & 41 & y & y \\
6 & F & Hispanic & 35 & y & y
\end{tabular}

Survey results.

The first survey question was regarding Mosston's Practice Style B and was as follows.

1. The teacher designs (or plans) several stations in the gym where students work on different parts of a skill or different skills. Students rotate among the stations and perform the tasks at their own pace. The teacher circulates, gives help, and provides feedback on how to improve performance. For example: in a basketball unit, the station activities may include dribbling in one area, jump shots second, passing in third area, and 
free throws in a fourth area. In a gymnastics unit the different station activities may include tumbling, balance beam, rope-climbing, or jumping." 
Table 2

$\underline{\text { Style B Results }}$

Teachers Did They

Pick the Do they

Correct use the If Yes,

Style (?) Style? What Units? If No, Why Not?

\begin{tabular}{|c|c|c|c|c|}
\hline 1 & B & $\mathrm{y}$ & $\begin{array}{l}\text { basketball } \\
\text { of } 10\end{array}$ & \\
\hline 2 & B & $\mathrm{n}$ & & $\begin{array}{l}\text { time issues/class } \\
\text { sizes }\end{array}$ \\
\hline 3 & $\mathrm{~B}$ & $\mathrm{n}$ & & time issues \\
\hline 4 & B & $\mathrm{y}$ & $\begin{array}{l}\text { soccer } 6 \text { of } \\
10\end{array}$ & \\
\hline 5 & B & $\mathrm{y}$ & $\begin{array}{l}\text { fitness } 15 \text { of } \\
30\end{array}$ & \\
\hline 6 & $\mathrm{~B}$ & $\mathrm{y}$ & $\begin{array}{l}\text { basketball } 5 \\
\text { of } 10\end{array}$ & \\
\hline
\end{tabular}

For question (1), all of the 6 teachers recognized this style correctly using the description. Four of six teachers claim that they used this style the previous years. Two teachers used this style during a basketball unit 5 of 10 lessons. Another teacher used it 15 of 30 lessons in a fitness unit, and another teacher used in 6 of 10 times in a soccer unit. Teachers 3 and 4 said they were unable to use this teaching style stating time issues and class sizes as a concern.

The second survey question was regarding Mosstons Style F and was as follows.

2. The teacher employs an investigating approach by asking the students a series of specific questions that have a predicted target answer. This series of questions are logically designed to lead the learners to a concept or principal that the teacher wanted them to learn. The students did not know this info before. It is not a review lesson. For 
example: the teacher asks the students specific questions about the activity to help lead them to the correct answer or idea. For example: in a shot-put unit the teacher may want you to figure out the best way to put a shot. The teacher would ask you questions to help lead you to the correct answer. The questions could be:

1) What is the primary purpose of putting the shot in competition?

Anticipated Response: To put it as far as possible.

2) To achieve a far distance, what does the body need?

Anticipated Response: Strength, Power! (Correct!)

3) What else?

Anticipated Response: Speed (Good)

4) In the total motion of putting the shot (starting point, middle release), where should the power and speed reach the maximum?

Anticipated Response: At the point of release! (Correct!)

\section{Table 3}

$\underline{\text { Style F Results }}$

\begin{tabular}{lllll} 
Teachers & $\begin{array}{l}\text { Did they Pick } \\
\text { the Correct } \\
\text { Style (?) }\end{array}$ & $\begin{array}{l}\text { Do they use the } \\
\text { style? }\end{array}$ & $\begin{array}{l}\text { If Yes, What } \\
\text { Units? }\end{array}$ & $\begin{array}{l}\text { If No, Why } \\
\text { Not? }\end{array}$ \\
\hline 1 & F & N & $\begin{array}{l}\text { time } \\
\text { issues/class size } \\
\text { time }\end{array}$ \\
2 & H & N & & $\begin{array}{l}\text { issues/class size } \\
\text { time issues } \\
\text { time issues }\end{array}$ \\
3 & F & N & & \\
5 & F & N & bowling 5 of 30 & \\
6 & F & Y & track 10 of 20 & \\
\hline
\end{tabular}

For question (2), five of the six teachers recognized this style correctly using the description. Two teachers from that five indicated that they use this method of teaching in 
a bowling class, and Track and Field. Teacher \#5 said they use this method for 5 of 20 lessons in a bowling unit. The four other teachers who do not use this method all stated time issues and class sizes as their reason for not using this teaching method during the previous term. Teacher \#2 confused this description with the Divergent Discovery Style, and claimed he did not use this style because of time issues.

The third survey question was regarding Mosston's Style K and was as follows.

3. The student works independently and separately from the in-school P.E. class. This student works totally on his/her own and decides everything about learning experience including the skills to be learned, time frame to practice (daily, weekly), and how to be assessed. The teacher is not involved in this experience except to make sure the student is progressing towards the goals he/she has set for themselves. The teacher accepts the student's decision about learning. For example: a student decides that s/he wants to learn about yoga. The student makes a plan to learn yoga by what to learn, how to learn it, when /where to learn it, and how much the physical education teacher will be involved.

$\underline{\text { Table } 4}$

\section{Style K Results}

\begin{tabular}{|c|c|c|c|c|}
\hline Teachers & $\begin{array}{l}\text { Did they Pick } \\
\text { the Correct } \\
\text { Style (?) }\end{array}$ & $\begin{array}{l}\text { Do they use the } \\
\text { style? }\end{array}$ & $\begin{array}{l}\text { If Yes, What } \\
\text { Units? }\end{array}$ & $\begin{array}{l}\text { If No, Why } \\
\text { Not? }\end{array}$ \\
\hline 1 & $\mathrm{~K}$ & $\mathrm{~N}$ & & liability \\
\hline 2 & $\mathrm{~K}$ & $\mathrm{~N}$ & & liability \\
\hline 3 & $\mathrm{~K}$ & $\mathrm{~N}$ & & $\begin{array}{l}\text { liability } \\
\text { student's }\end{array}$ \\
\hline 4 & $\mathrm{~K}$ & $\mathrm{~N}$ & & $\begin{array}{l}\text { maturity } \\
\text { not conducive }\end{array}$ \\
\hline 5 & $\mathbf{J}$ & $\mathrm{N}$ & & to P.E. \\
\hline 6 & $\mathrm{~J}$ & $\mathrm{~N}$ & & liability \\
\hline
\end{tabular}


Question (\#3) gives teachers a description of the Self-Teaching Style. Four of the six teachers were able to recognize this style using the description provided. Teachers \#5 and \#6 mistakenly thought it was Learner Initiated Style. No teachers used this method during their last semester units. Teachers reasoning included liability, students' maturity level, and that it was not conducive to their unit for not using this teaching style.

The fourth survey question was regarding Mosston's Style C and was as follows.

4. Two students work together on a task that the teacher has designed. Student "1" (a.k.a. the doer) practices while student "2" (a.k.a. the observer/recorder) gives immediate and on-going feedback to student " 1 " using the teacher prepared criteria (checklist of the task). At the end of the first practice the students switch roles so student "1" now becomes the observer/recorder, and student " 2 " becomes the doer. For example, if the teacher wants the pair to work on throwing a ball, student " 1 " throws the ball, while student "2" watches the performance and uses the teacher-prepared checklist on throwing cues/errors to record student " 1 "'s skill performance. Student " 2 " offers feedback to student " 1 " in order for student " 1 " to become more proficient in the skill. The partners switch positions in order to experience both roles. This teaching style also is characterized by having the teacher only communicating with the observer/recorder, to help him/her gain experience in giving proper feedback to their peers.

\section{$\underline{\text { Table } 5}$}

\section{$\underline{\text { Style C Results }}$}

\begin{tabular}{lllll} 
& $\begin{array}{l}\text { Did they Pick } \\
\text { the Correct }\end{array}$ & $\begin{array}{l}\text { Do they use the } \\
\text { style? }\end{array}$ & $\begin{array}{l}\text { If Yes, What } \\
\text { Units? }\end{array}$ & $\begin{array}{l}\text { If No, Why } \\
\text { Net? }\end{array}$ \\
\hline 1 & Style (?) & y & tennis 5 of 10 & \\
2 & C & y & golf 4 of 8 & \\
3 & C & basketball 5 of &
\end{tabular}




\begin{tabular}{lllll}
4 & C & y & tennis 3 of 6 & \\
5 & F & not conducive & & \\
6 & C & y & dance 5 of 10 & \\
\hline
\end{tabular}

Question (\#4) gives teacher a description of the Reciprocal Style. Five of the six teachers were able to recognize this style using the description provided. One teacher \#5 mistakenly thought it was the Guided-Discovery Style. The five teachers that were able to recognize this style all used it in their previous term. Teachers used this style in the following units: tennis 5 of 10 lessons; golf 4 of 8 lessons and 3 of 6 lessons; basketball 5 of 10 lessons; and dance 5 of 10 lessons. The one teacher \#5 answered incorrectly, stated they did not use this style at all because it was not conducive to PE.

The fifth survey question was regarding Mosston's Style I and was as follows.

5. The teacher makes general subject matter logistical decisions for the students. The students make decisions about how to investigate the general subject matter topic, produce questions that lead to specific focus within the general topic, produce the questions that result in identifying the processes and procedures, discover solutions/movements and designate the performance criteria. The students design a personal learning curriculum that is new (not something that was taught before). The teacher is kept informed by the student, and the student consults with the teacher about specifics of designing their personal learning curriculum. Since the curriculums are personalized, no two students' curriculum will look alike. For example: the teacher selects the subject matter area (i.e., how would you go about learning how to skateboard?). The students must design the questions/problems associated with learning how to skateboard and seek the solutions. 


\section{Table 6}

$\underline{\text { Style I Results }}$

\begin{tabular}{|c|c|c|c|c|}
\hline Teachers & $\begin{array}{l}\text { Did they Pick } \\
\text { the Correct } \\
\text { Style (?) }\end{array}$ & $\begin{array}{l}\text { Do they use the } \\
\text { style? }\end{array}$ & $\begin{array}{l}\text { If Yes, What } \\
\text { Units? }\end{array}$ & $\begin{array}{l}\text { If No, Why } \\
\text { Not? }\end{array}$ \\
\hline 1 & I & $\mathrm{n}$ & & $\begin{array}{l}\text { no time } \\
\text { time } \\
\text { issues/class }\end{array}$ \\
\hline 2 & I & $\mathrm{n}$ & & sizes \\
\hline 3 & I & $\mathrm{n}$ & & time \\
\hline 4 & I & $\mathrm{n}$ & & time \\
\hline 5 & $\mathrm{~F}$ & $\mathrm{n}$ & & not conducive \\
\hline 6 & I & $\mathrm{n}$ & & time \\
\hline
\end{tabular}

Question (\#5) gives the teacher a description of the Learner-Initiated Style. Five of the six teachers were able to recognize this style correctly using the provided description. One teacher confused it with the Guided Discovery Style. Five teachers stated that they did not use this style because of time issues and class sizes, and one teacher claimed it was not conducive to PE.

The sixth survey question was regarding Mosston's Style J and was as follows.

6. This style occurs when a student approaches the teacher and initiates a request to do something other than what the class is doing. The student initiates this experience, and is responsible for designing the experience. The student has periodic informational consultations with the teacher. The student decides what will be learned as well as how it 
will be learned. The teacher and students set up basic criteria, but the student is responsible for all the decisions about how and what to learn. The teacher is available if the student requests it.

$\underline{\text { Table } 7}$

\section{$\underline{\text { Style J Results }}$}

\begin{tabular}{|c|c|c|c|c|}
\hline Teachers & $\begin{array}{l}\text { Did they Pick } \\
\text { the Correct } \\
\text { Style (?) }\end{array}$ & $\begin{array}{l}\text { Do they use the } \\
\text { style? }\end{array}$ & $\begin{array}{l}\text { If Yes, What } \\
\text { Units? }\end{array}$ & $\begin{array}{l}\text { If No, Why } \\
\text { Not? }\end{array}$ \\
\hline 1 & $\mathbf{J}$ & $\mathrm{n}$ & & $\begin{array}{l}\text { no time } \\
\text { time } \\
\text { issues/class }\end{array}$ \\
\hline 2 & $\mathrm{~J}$ & $\mathrm{n}$ & & $\begin{array}{l}\text { sizes } \\
\text { time } \\
\text { issues/class }\end{array}$ \\
\hline 3 & $\mathbf{J}$ & $\mathrm{n}$ & & sizes \\
\hline 4 & $\mathrm{~J}$ & $\mathrm{n}$ & & too much work \\
\hline 5 & I & $\mathrm{n}$ & & not conducive \\
\hline 6 & $\mathrm{~J}$ & $\mathrm{n}$ & & time issues \\
\hline
\end{tabular}

Question (\#6) gives the teacher a description of the Learner Designed Individual

Style. Five of the six teachers were able to correctly recognize this style using the description provided. One teacher confused this style with the Learner Initiated Style. No teachers included time issues, class sizes, too much work, and not conducive to PE.

The seventh survey question was regarding Mosston's Style D and was as follows.

7. Students work individually on a task and use a teacher prepared task checklist (criteria) to analyze their own performance. The checklist includes criteria the student can use to answer the following questions when performing a skill: (1) where is the error? (2) 
Why did the error occur? (3) How do I correct the error? The criteria sheet provides cues on how the task is to be performed and provides feedback to the students while she/he practices the task.

\section{Table 8}

Style D Results

\begin{tabular}{|c|c|c|c|c|}
\hline Teachers & $\begin{array}{l}\text { Did they Pick } \\
\text { the Correct } \\
\text { Style (?) }\end{array}$ & $\begin{array}{l}\text { Do they use the } \\
\text { style? }\end{array}$ & $\begin{array}{l}\text { If Yes, What } \\
\text { Units? }\end{array}$ & $\begin{array}{l}\text { If No, Why } \\
\text { Not? }\end{array}$ \\
\hline 1 & $\mathrm{D}$ & $\mathrm{y}$ & $\begin{array}{l}\text { tennis } 5 \text { of } 10 \\
\text { basketball } 1 \text { of }\end{array}$ & \\
\hline 2 & D & $\mathrm{y}$ & 10 & \\
\hline 3 & D & $\mathrm{y}$ & tennis 3 of 6 & \\
\hline 4 & D & $\mathrm{y}$ & $\begin{array}{l}\text { soccer } 5 \text { of } 10 \\
\text { bowling } 25 \text { of }\end{array}$ & \\
\hline 5 & $\mathrm{D}$ & $\mathrm{y}$ & $\begin{array}{l}30 \\
\text { basketball } 3 \text { of }\end{array}$ & \\
\hline 6 & D & $\mathrm{y}$ & 10 & \\
\hline
\end{tabular}

Question (\#7) gives the teacher a description of the Self-Check Style. All six teachers recognized this style correctly using the description provided. All teachers claimed they used this style during the last term. Units included: tennis 5 of 10 lessons and 3 of 6 lessons; basketball 1 of 10 lessons and 3 of 10 lessons; soccer 5 of 10 lessons, and bowling 25 of 30 lessons.

The eighth survey question was regarding Mosston's Style E and was as follows.

8. The defining characteristic of this style is that students with varying degrees of skill participate in the same task by selecting the level of difficulty of which they can 
perform. For example: the teacher designs an activity including various possible levels for the students to try based on their skill level. All students participate in the same task. Each student, however, surveys the available levels in the task, selects an entry point, practices the task at the entry point, if necessary makes an adjustment in the task level by checking performance against the criteria. Based on the criteria, the student can stay at the same entry point, or select a more difficult level, or less difficult/easier level. For example: students can chose to perform (a) wall pushups, (b) modified (on-knee) push ups, regulation push ups (on balls of feet), (d) incline push ups, inverted push ups (hand stand position). They can also choose how many push ups in each position they want to do: (a) wall push ups: 5 times; 10 times; 15 times (b) modified push ups: 5 times; 10 times; 15 times, etc.

\section{Table 9}

\section{$\underline{\text { Style E Results }}$}

\begin{tabular}{|c|c|c|c|c|}
\hline Teachers & $\begin{array}{l}\text { Did they Pick } \\
\text { the Correct } \\
\text { Style (?) }\end{array}$ & $\begin{array}{l}\text { Do they use the } \\
\text { style? }\end{array}$ & $\begin{array}{l}\text { If Yes, What } \\
\text { Units? }\end{array}$ & $\begin{array}{l}\text { If No, Why } \\
\text { Not? }\end{array}$ \\
\hline 1 & $\mathrm{E}$ & $\mathrm{y}$ & track 2 of 10 & \\
\hline 2 & $\mathrm{E}$ & $\mathrm{n}$ & & $\begin{array}{l}\text { more for } \\
\text { special ed } \\
\text { special }\end{array}$ \\
\hline 3 & $\mathrm{E}$ & $\mathrm{n}$ & & education \\
\hline 4 & E & $\mathrm{n}$ & & no need to \\
\hline 5 & $\mathrm{H}$ & $\mathrm{y}$ & skating 5 of 10 & \\
\hline 6 & $\mathrm{E}$ & $\mathrm{n}$ & & $\begin{array}{l}\text { not conducive } \\
\text { to P.E. }\end{array}$ \\
\hline
\end{tabular}

Question (\#8) gives teacher a description of the Inclusion Style. Five of the six teachers were able to correctly recognize this style using the description provided. One teacher confused this description with the Divergent Discovery Style. Only two teachers 
claimed they used this style in their previous term. One teacher used this style for Track and Field 2 of 10 lessons, and another used this style during an inline-skating unit 5 of 10 lessons. Two teachers reasoning for not using this method were that this style would be more suited for Special Ed students, and one teacher claimed there was no need to use this style at all with their students.

The ninth survey question was regarding Mosston's Style H and was as follows.

9. The characteristic of this style is to have multiple responses to a single question/situation within a specific cognitive operation. For example: in a dance unit the teacher shows the students five different dance moves. Each student is directed to use these five dance moves to make a dance routine. Different students will produce different dance routines, but every routine must include the five dance moves.

\section{Table 10}

Style H Results

\begin{tabular}{|c|c|c|c|c|}
\hline Teachers & $\begin{array}{l}\text { Did they Pick } \\
\text { the Correct } \\
\text { Style (?) }\end{array}$ & $\begin{array}{l}\text { Do they use the } \\
\text { style? }\end{array}$ & $\begin{array}{l}\text { If Yes, What } \\
\text { Units? }\end{array}$ & $\begin{array}{l}\text { If No, Why } \\
\text { Not? }\end{array}$ \\
\hline 1 & $\mathrm{H}$ & $\mathrm{n}$ & & $\begin{array}{l}\text { no time } \\
\text { time } \\
\text { issues/class }\end{array}$ \\
\hline 2 & $\mathrm{H}$ & $\mathrm{n}$ & & sizes \\
\hline 3 & $\mathrm{H}$ & $\mathrm{n}$ & & time/class sizes \\
\hline 4 & $\mathrm{H}$ & $\mathrm{n}$ & & time \\
\hline 5 & $\mathrm{E}$ & $\mathrm{n}$ & & not conducive \\
\hline 6 & $\mathrm{H}$ & $\mathrm{n}$ & & not conducive \\
\hline
\end{tabular}

Question (\#9) gives teachers a description of the Divergent Discovery Style. Five out of six teachers were able to recognize this style correctly using the description provided. One teacher confused it with the Inclusion Style. All teachers claimed they did 
not use this style during their previous term. Teachers' reasoning for not using this style included time issues, class sizes, and that the method was not conducive to PE.

The tenth question was regarding Mosston's Style A and was as follows:

10. The defining characteristic of this style is precision performance, that is, reproducing a predicted response or performance on cue. The teacher makes all the decisions and the students are to follow these directions on cue, for example: when learning and performing line/square/swing/aerobic/dancing; synchronized swimming routing; rhythmic/Olympic gymnastic routines; diving board skills; cheerleading; tai-chi; etc.-any instance where the students must execute the performance decisions on the teacher's cue.

$\underline{\text { Table } 11}$

$\underline{\text { Style A Results }}$

\begin{tabular}{|c|c|c|c|c|}
\hline Teachers & $\begin{array}{l}\text { Did they Pick } \\
\text { the Correct } \\
\text { Style (?) }\end{array}$ & $\begin{array}{l}\text { Do they use the } \\
\text { style? }\end{array}$ & $\begin{array}{l}\text { If Yes, What } \\
\text { Units? }\end{array}$ & $\begin{array}{l}\text { If No, Why } \\
\text { Not? }\end{array}$ \\
\hline 1 & $\mathrm{~A}$ & $\mathrm{y}$ & $\begin{array}{l}\text { karate } 8 \text { of } 10 \\
\text { gymnastics } 3\end{array}$ & \\
\hline 2 & $\mathrm{~A}$ & $\mathrm{y}$ & $\begin{array}{l}\text { of } 6 \\
\text { stretching } 10 \text { of }\end{array}$ & \\
\hline 3 & A & $\mathrm{y}$ & $\begin{array}{l}10 \\
\text { warm-ups } 10\end{array}$ & \\
\hline 4 & A & $\mathrm{y}$ & of 10 & \\
\hline 5 & A & $\mathrm{y}$ & fitness 10 of 30 & \\
\hline 6 & $\mathrm{~A}$ & $\mathrm{y}$ & fitness 10 of 20 & \\
\hline
\end{tabular}

Question (\#10) gives teachers a description of the Command Style. All six teachers recognize this style using the description provided. All six teachers claim they have used this style in the previous term. Teachers claim they have used this style in the 
following units: karate 8 of 10 lessons; gymnastics 3 of 6 lessons; stretching 10 of 10 lessons; warm-ups 10 of 10 lessons; and fitness 10 of 30 lessons and 10 of 20 lessons.

The eleventh question was regarding Mosston's Style G and was as follows.

11. The defining characteristic of this style is to have the students figure out the correct (predetermined) response to a targeted concept (designed by the teacher) by engaging in reasoning, questioning, and logic to sequentially make connections about the content, and through this process find the predetermined correct answer. For example: for students to determine the effect of posture and speed of movement on the heart rate, the teacher gives the students a series of physical tasks to complete: taking their heart rate when lying down, sitting up, standing up, walking around the gym, fast walk, jog, and after running around the gym. Students then participate in volleyball, flag football, basketball, tennis, etc. Students answer questions regarding how their heart rate changed during each task. They are told to draw a conclusion based on their experience and the relationship between their heart rate and exercise patterns. Students will realize which of these exercises are beneficial to increasing their endurance. The teacher never told the students which exercises would help increase their endurance, but while answering questions the students asked questions while investigating, and came to the conclusion on their own.

\section{Table 12}

$\underline{\text { Style G Results }}$

\begin{tabular}{|c|c|c|c|c|}
\hline Teachers & $\begin{array}{l}\text { Did they Pick } \\
\text { the Correct } \\
\text { Style (?) }\end{array}$ & $\begin{array}{l}\text { Do they use the } \\
\text { style? }\end{array}$ & $\begin{array}{l}\text { If Yes, What } \\
\text { Units? }\end{array}$ & $\begin{array}{l}\text { If No, Why } \\
\text { Not? }\end{array}$ \\
\hline 1 & $\mathrm{G}$ & no & & $\begin{array}{l}\text { no time/clas } \\
\text { sizes }\end{array}$ \\
\hline
\end{tabular}




\begin{tabular}{|c|c|c|c|c|}
\hline 2 & $\mathrm{G}$ & no & & $\begin{array}{l}\text { no time } \\
\text { no time/class }\end{array}$ \\
\hline 3 & $\mathrm{G}$ & no & & sizes \\
\hline 4 & $\mathrm{G}$ & no & & No time \\
\hline 5 & $\mathrm{G}$ & $\mathrm{y}$ & fitness 5 of 25 & \\
\hline 6 & $\mathrm{G}$ & no & & no time \\
\hline
\end{tabular}

Question (\#11) gives teachers a description of the Convergent Discovery Style.

All six teachers were able to recognize this style correctly using the description provided.

Five of the six teachers claim they do not use this style because of time issues and class sizes. One teacher claimed they use this style in a fitness unit 5 of 25 lessons. 


\section{CHAPTER 5}

\section{DISCUSSION}

The table labeled Overall Results (See Appendix C) was created for an overall look at the physical education teachers' ability to recognize the correct style from the descriptor provided, how many teachers used the style, what unit they used it in, and for how many lessons out of the total lessons taught in that unit.

When examining the data in column \#1, results showed that out of the six teachers' $(5 / 6)$ or $(6 / 6)$ teachers were able to recognize the style descriptors. In one case only $(4 / 6)$ teachers were able to recognize the descriptor. This was the case of the Self-Teaching description. These findings lead us to believe that the teachers surveyed at the three high schools in Santa Barbara have had teacher training that allowed them to be able to recognize a majority of the styles by the example description provided in the survey.

When examining the data in column $\# 2$, it showed clearly that teachers were not as comfortable using the teaching styles in the Spectrum that ventured past the Discovery Threshold. These were the styles that led to more independence and student decision making, making the teacher participation limited. All six teachers reported to not using four of these styles in their previous semester; Learner Designed, Divergent Discovery, Learner Initiated, and Self Teaching. Only one teacher claimed to have used the Convergent Discovery Style, and two reported using the Guided Discovery Style. Examining the teacher usage of styles with the Spectrum Styles (A-E) that have not crossed the Discovery Threshold compared to styles (F-K) shows that the six teachers from Santa Barbara school district that the researcher surveyed felt more comfortable 
when the students' decision making opportunities are limited.

When examining the data in column \#3, results demonstrate that the main reason that teachers do not use these styles is because of class time and class size. Another interesting part of the data was that most of the teachers did not use the Inclusion Style because they believed it should be used for Special Education students who they did not teach.

After examining the data provided by the six Physical Education teachers at Santa Barbara School District, conclusions for this pilot study were in several areas. First teachers definitely did have enough training to be able to recognize the styles descriptors provided by this teacher questionnaire. In fact, all teachers answered correctly with at least $85 \%$ accuracy. This data suggested that teachers are aware of the different teaching styles they can use to reach students.

These data also showed that teachers are reluctant to let go of their control and to shift more decision-making skills and responsibility to the student. These data are consistent with the phenomenon that the teachers felt more comfortable teaching when they are in command. The teachers' responses state liability is the major issue when allowing students to venture closer to the self-teaching style. This suggests that the six physical education teachers in Santa Barbara did not use these styles because of personal liability risk.

The most compelling data found was in the last column, however. The overall main reason for using different styles of teaching was class size ratio, and class time. This data suggests that in order to allow teachers to teach using a variety of teaching styles created to reach different learner profiles, researchers must look into appropriate class 
sizes and class duration.

Finally, the instrument developed here, or the teacher questionnaire, did provide valuable insights into teacher preparation programs. Because of the size of the population surveyed, the researcher could only make assumptions for those six teachers. Future studies would be beneficial if a larger group of teachers was surveyed. Education is being driven by data based standard instruction, so questionnaires and surveys could help answer questions regarding the amount of opportunities for success provided in physical education departments across the country. 


\section{REFERENCES}

Ashworth, S. (1992). The Spectrum and Teacher Education. Journal of Physical Education Recreation and Dance, 32- 53.

Byra, M. (2000). A review of spectrum research: The contributions of two eras. Quest, 52. 229-245.

Costello, J.A. (1977). A descriptive analysis of student behavior in elementary school physical education classes. Unpublished Doctoral Dissertation, Columbia University, New York.

Cothran, D.J., Kullina, P.H, Banville, G.M., Amade-Escot, C., Euichang, C., Sarmento, P., McDonald, D., MacPhail, A., Richard, J.F. (2003). A Cross-Cultural Investigation of The Usage of Teaching Styles. Paper presented at the Annual Meeting of the American Educational Reasearch Association, Chicago, II.

Cothran,D.J., Kullina, P.H, Ward, E., (2000). Students' Experiences with and Perceptions of Teaching Styles. The Journal of Research and Development in Education. V 33,5, 93-101.

Gerney, P., \& Dort, A. (1992). The Spectrum Applied: Letters From The Trenches Journal of Physical Education Recreation and Dance, 36-39,

Kounin, J. (1977). Discipline and group management in classrooms. Melbourne, FL: R.E. Krieger Publishing.

Kulinna, P. H., \& Cothran, D.J , Zhu, W., (2000). Teachers' Experiences and Perceptions Of Mosston's Spectrum. How Do They Compare With Students? Paper presented at the annual meeting of the American Educational Research Association, New Orleans, 
Louisiana, April, 2000.

Kulinna, P. H., \& Cothran, D.J. (2002). Physical Education Teachers' Self-Reported and Perceptions Of Various Teaching Styles. In Publication.

Mosston, M. (1992). Tug-O-War, No More: Meeting Teaching-Learning Objectives Using The Spectrum of Teaching Styles. Journal of Physical Education Recreation and Dance. 27-31.

Mosston, M., \& Ashworth, S., (2002). Teaching Physical Education, $5^{\text {th }}$ Edition. Benjamin Cummings, San Francisco, CA.

Mueller, R., \& Mueller, S., (1992). The Spectrum of Teaching Styles and Its Role in Conscious Deliberate Teaching. Journal of Physical Education Recreation and Dance.32-53.

Rink, J. E. (2002). Teaching Physical Education For Higher Learning, $4^{\text {th }}$ Edition. McGraw-Hill, New York, NY.

Roshenshine, B., \& Furst, F. (1971). Research in teacher performance criteria. In B. Smith (Ed.) Research in teacher education. Englewood Cliffs, NJ: Prentice -Hall.

Soar, R., \& Soar, R, M. (1979). Emotional climate and management. In P. Peterson \& Waldbergs (Eds.), Research on teaching: Concepts, findings and implications. Berkely, CA: McCutchan Publising.

Tobey, C. (1974). A descriptive analysis of the occurrence of augmented feedback in Physical Education classes. Unpublished Doctoral dissertation, Columbia University Teachers College, New York. 


\section{APPENDIX A}

Greg Pierce

4054 Via Zorro Ave

Santa Barbara, Ca 93107

Phone (805) 403-7306

June 2nd, 2006

Dear Sir or Madam:

My name is Greg Pierce and I am a currently working on my Master's of Science in Kinesiology at California Polytechnic State University, San Luis Obispo. I am also a Physical Education teacher at San Marcos High School in Santa Barbara. I am currently working on a project to fulfill partial requirements for my degree.

The project includes validating a questionnaire I created that leads insight to the different teaching methodologies high school physical education teachers use. Please take a moment to complete the questionnaire (attached). The questionnaire should take 10-20 minutes to complete, however, please take as much time as you need. I thank you in advance for taking the time out of your busy schedule to complete the questionnaire.

Also note that although participation is voluntary, please consider partaking in my project. The information you contribute will greatly contribute to the body of physical education research knowledge. Your answers will be completely anonymous and will not be seen by anybody but myself. Please understand that completing the survey will in no way affect your job status. As stated previously, this data will only be seen by me in order to complete my research project. I only ask that while you are completing this survey, you give it your full attention, answer truly, and do not share your answers with other teachers participating in this project. I hope that you decide to volunteer your time, and I thank you very much for your cooperation.

Sincerely,

Greg Pierce 


\section{Teacher Questionnaire}

\section{APPENDIX B}

Please follow directions, and answer the questions to the best of your knowledge. Listed below are eleven different teaching styles A-K. Following the teaching styles list are eleven different Methods/Examples. Please

1. Place the letter of the (teaching style) that you feel correctly matches each Method/Example in the designated section provided, located next to the end of the example, and

2. Answer the additional questions when applicable.

\section{Teaching Styles}
A. Command Style
G. Convergent Discovery Style
B. Practice Style
H. Divergent Discovery Style
C. Reciprocal Style
I. Learner Designed Individual Style
D. Self-Check Style
J. Learner Initiated Style
E. Inclusion Style
K. Self-Teaching Style
F. Guided Discovery Style

\section{Method/Example 1}

The teacher designs (or plans) several stations in the gym where students work on different parts of a skill or different skills. Students rotate among the stations and perform the tasks at their own pace. The teacher circulates, gives help, and provides feedback on how to improve performance. For example: in a basketball unit, the station activities may include dribbling in one area, jump shots second, passing in third area, and free throws in a fourth area. In a gymnastics unit the different station activities may include tumbling, balance beam, rope-climbing, or jumping."

\section{Question 1}

a. What teaching style does the above example/method best represent?

b. Do you use this teaching style when teaching any of your units? Yes No

If you answered "Yes," please answer "c" and then move to question \#2. If you answered "No" answer "d" and then move to question \#2.

c. Please list the unit and how many lessons per unit do you use this style? Example:

Unit- Basketball I use this teaching style 5 times out of 20 lessons.

Unit-

Unit-

UnitI use this teaching style I use this teaching style I use this teaching style times out of times out of times out of lessons. lessons. lessons.

d. Please list the reasons why you do not use this teaching style. 


\section{Method/Example 2}

The teacher employs an investigating approach by asking the students a series of specific questions that have a predicted target answer. This series of questions are logically designed to lead the learners to a concept or principal that the teacher wanted them to learn. The students did not know this info before. It is not a review lesson. For example" The teacher asks the students specific questions about the activity to help lead them to the correct answer or idea. For example: in a shot-put unit the teacher may want you to figure out the best way to put a shot. The teacher would ask you questions to help lead you to the correct answer. The questions could be:

5) What is the primary purpose of putting the shot in competition?

Anticipated Response: To put it as far as possible.

6) To achieve a far distance, what does the body need?

Anticipated Response: Strength, Power! (Correct!)

7) What else?

Anticipated Response: Speed (Good)"

8) In the total motion of putting the shot (starting point, middle release), where should the power and speed reach the maximum?

Anticipated Response: At the point of release! (Correct!)

\section{Question 2}

a. What teaching style does the above example/method best represent?

b. Do you use this teaching style when teaching any of your units? Yes No

If you answered "Yes," please answer "c" and then move to question \#3. If you answered "No" answer "d" and then move to question \#3.

c. Please list the unit and how many lessons per unit do you use this style?

UnitI use this teaching style times out of lessons. UnitI use this teaching style times out of UnitI use this teaching style times out of lessons.

d. Please list the reasons why you do not use this teaching style.

\section{Method/Example 3}

The student works independently and separately from the in-school P.E. class. This student works totally on his/her own and decides everything about learning experience including the skills to be learned, time frame to practice (daily, weekly), and how to be assessed. The teacher is not involved in this experience except to make sure the student is progressing towards the goals he/she has set for himself. The teacher accepts the student's decision about learning. For example: a student decides that s/he wants to learn about yoga. The student makes a plan to learn yoga by what to learn, how to learn it, when /where to learn it, and how much the physical education teacher will be involved. 
Question 3

a. What teaching style does the above example/method best represent?

b. Do you use this teaching style when teaching any of your units? Yes No

If you answered "Yes," please answer "c" and then move to question \#4. If you answered "No" answer "d" and then move to question \#4.

c. Please list the unit and how many lessons per unit do you use this style?

UnitI use this teaching style times out of lessons. UnitI use this teaching style times out of lessons.

UnitI use this teaching style times out of lessons.

d. Please list the reasons why you do not use this teaching style.

\section{Method/Example 4}

Two students work together on a task that the teacher has designed. Student "1" (a.k.a. the doer) practices while student " 2 " (a.k.a. the observer/recorder) gives immediate and on-going feedback to student " 1 ", using the teacher prepared criteria (checklist of the task).At the end of the first practice the students switch roles so student " 1 " now becomes the observer/recorder, and student " 2 " becomes the doer.. For example: if the teacher wants the pair to work on throwing a ball, student " 1 " throws the ball, while student " 2 " watches the performance and uses the teacher prepared checklist on throwing cues/errors to record students " 1 "'s skill performance. Student " 2 " offers feedback to student " 1 " in order for student " 1 " to become more proficient in the skill. The partners switch positions in order to experience both roles. This teaching style also is characterized by having the teacher only communicating with the observer/recorder, to help him/her gain experience in giving proper feedback to their peers.

Question 4

a. What teaching style does the above example/method best represent?

b. Do you use this teaching style when teaching any of your units? Yes No

If you answered "Yes," please answer "c" and then move to question \#5. If you answered "No" answer "d" and then move to question \#5.

c. Please list the unit and how many lessons per unit do you use this style?

Unit-

Unit-

Unit-
I use this teaching style I use this teaching style I use this teaching style times out of times out of times out of lessons. lessons. lessons.

d. Please list the reasons why you do not use this teaching style. 


\section{Method/Example 5}

The teacher makes general subject matter logistical decisions for the students. The students make decisions about how to investigate the general subject matter topic, produce questions that lead to specific focus within the general topic, produce the questions that result in identifying the processes and procedures, discover solutions/movements and designate the performance criteria. The students design a personal learning curriculum that is new (not something that was taught before). The teacher is kept informed by the student, and the student consults with the teacher about specifics of designing their personal learning curriculum. Since the curriculums' are personalized, no two student's curriculum will look alike. For example: the teacher selects the subject matter area (i.e. "how would you go about learning how to skateboard?"). The students must design the questions/problems associated with learning how to skateboard and seeks the solutions.

\section{Question 5}

a. What teaching style does the above example/method best represent?

b. Do you use this teaching style when teaching any of your units? Yes No

If you answered "Yes," please answer "c" and then move to question \#6. If you answered "No" answer "d" and then move to question \#6.

c. Please list the unit and how many lessons per unit do you use this style?
Unit-_ I use this teaching style times out of _ lessons.
Unit-__ I use this teaching style_times out of _ lessons.
Unit-_ I use this teaching style__times out of ___lessons.

d. Please list the reasons why you do not use this teaching style.

\section{Method/Example 6}

This style occurs when a student approaches the teacher and initiates a request to do something other than what the class is doing. The student initiates this experience, and is responsible for designing the experience. The student has periodic informational consultations with the teacher. The student decides what will be learned as well as how it will be learned. The teacher and students set up basic criteria, but the student is responsible for all the decisions about how and what to learn. The teacher is available if the student requests it.

\section{Question 6}

a. What teaching style does the above example/method best represent? b. Do you use this teaching style when teaching any of your units? Yes No 
If you answered "Yes," please answer "c" and then move to question \#7.

If you answered "No" answer " $d$ " and then move to question \#7.

c. Please list the unit and how many lessons per unit do you use this style?

UnitI use this teaching style times out of lessons. UnitI use this teaching style times out of lessons.

UnitI use this teaching style times out of lessons.

d. Please list the reasons why you do not use this teaching style.

\section{Method/Example 7}

Students work individually on a task and use a teacher prepared task checklist (criteria) to analyze their own performance. The checklist includes criteria the student can use to answer the following questions when performing a skill: (1) where is the error? (2) why did the error occur? (3) how do I correct the error? The criteria sheet provides cues on how the task is to be performed and provides feedback to the students while s/he practices the task.

For example: if the task is shooting a free-throw in basketball, the checklist might read:

\begin{tabular}{|l|l|l|l|l|}
\hline $\begin{array}{l}\text { Task } \\
\text { Description }\end{array}$ & $\underline{\text { Skill }}$ & $\underline{\text { Cue }}$ & Alternate Cue & Common Errors \\
\hline $\begin{array}{l}\text { Starting } \\
\text { position, free } \\
\text { throw }\end{array}$ & $\begin{array}{l}\text { Hand } \\
\text { Placement }\end{array}$ & $\begin{array}{l}\text { Fingers spread, } \\
\text { primary hand } \\
\text { middle finger } \\
\text { on air hole. } \\
\text { Other hand on } \\
\text { side supporting } \\
\text { the ball. }\end{array}$ & $\begin{array}{l}\text { Wide fingers, if } \\
\text { right handed } \\
\text { hold ball with } \\
\text { right hand in } \\
\text { middle of ball, } \\
\text { left hand placed } \\
\text { on side of ball } \\
\text { for support. }\end{array}$ & $\begin{array}{l}\text { Both hands are } \\
\text { placed on the } \\
\text { sides of the ball, } \\
\text { like during a } \\
\text { chest push pass. }\end{array}$ \\
\hline $\begin{array}{l}\text { Starting } \\
\text { position, free } \\
\text { throw }\end{array}$ & Stance & $\begin{array}{l}\text { Feet shoulder } \\
\text { width apart, } \\
\text { Knees bent. }\end{array}$ & $\begin{array}{l}\text { Good even } \\
\text { support, } \\
\text { pretend you are } \\
\text { about to sit } \\
\text { down, get low. }\end{array}$ & $\begin{array}{l}\text { Narrow stance, } \\
\text { no bend in } \\
\text { knees. }\end{array}$ \\
\hline
\end{tabular}

\section{Question 7}

a. What teaching style does the above example/method best represent?

b. Do you use this teaching style when teaching any of your units? Yes No

If you answered "Yes," please answer "c"' and then move to question \#8. If you answered "No" answer " $d$ " and then move to question \#8.

c. Please list the unit and how many lessons per unit do you use this style? UnitI use this teaching style times out of lessons. 
UnitI use this teaching style UnitI use this teaching style times out of lessons. times out of ___ lessons.

d. Please list the reasons why you do not use this teaching style.

\section{Method/Example 8}

The defining characteristic of this style is that students with varying degrees of skill participate in the same task by selecting the level of difficulty of which they can perform. For example: the teacher designs an activity including various possible levels for the students to try based on their skill level. All students participate in the same task. Each student, however, surveys the available levels in the task, selects an entry point, practices the task at the entry point, if necessary makes an adjustment in the task level by checking performance against the criteria. Based on the criteria, the student can stay at the same entry point, or select a more difficult level, or less difficult/easier level. For example: students can chose to perform (a) wall push ups, (b) modified (on-knee) push ups, regulation push ups ( on balls of feet),(d) incline push ups, inverted push ups ( hand stand position). They can also choose how many push ups in each position they want to do: (a) wall push ups: 5 times; 10 times; 15 times (b) modified push ups: 5 times; 10 times; 15 times, etc...

\section{Question 8}

a. What teaching style does the above example/method best represent? b. Do you use this teaching style when teaching any of your units? Yes No

If you answered "Yes," please answer "c" and then move to question \#9. If you answered "No" answer "d" and then move to question \#9.

c. Please list the unit and how many lessons per unit do you use this style? UnitUnitI use this teaching style UnitI use this teaching style times out of lessons. I use this teaching style times out of ___essons. times out of ___essons.

d. Please list the reasons why you do not use this teaching style.

\section{Method/Example 9}

The characteristic of this style is to have multiple responses to a single question/situation within a specific cognitive operation. For example: in a dance unit the teacher shows the 
students five different dance moves. Each student is directed to use these five dance moves to make a dance routine. Different students will produce different dance routines, but every routine must include the five dance moves.

\section{Question 9}

a. What teaching style does the above example/method best represent?

b. Do you use this teaching style when teaching any of your units? Yes No

If you answered "Yes," please answer "cc" and then move to question \#10. If you answered "No" answer "d" and then move to question \#10.

c. Please list the unit and how many lessons per unit do you use this style?

Unit-

Unit-

UnitI use this teaching style I use this teaching style I use this teaching style times out of times out of times out of lessons. lessons. lessons.

d. Please list the reasons why you do not use this teaching style.

\section{Method/Example 10}

The defining characteristic of this style is precision performance, that is, reproducing a predicted response or performance on cue. The teacher makes all the decisions and the students are to follow these directions on cue. For example: when learning and performing line/square/swing/aerobic/dancing; synchronized swimming routing; rhythmic/ Olympic gymnastic routines; diving board skills; cheerleading; tai-chi; etc.

Any instance where the students must execute the performance decisions on the teacher's cue.

\section{Question 10}

a. What teaching style does the above example/method best represent?

b. Do you use this teaching style when teaching any of your units? Yes No

If you answered "Yes," please answer "c" and then move to question \#11. If you answered "No" answer "d" and then move to question \#11.

c. Please list the unit and how many lessons per unit do you use this style?

Unit-

Unit-

Unit-
I use this teaching style I use this teaching style I use this teaching style times out of times out of times out of lessons. lessons. lessons.

d. Please list the reasons why you do not use this teaching style. 


\section{Method/Example 11}

The defining characteristic of this style is to have the students figure out the correct (predetermined) response to a targeted concept (designed by the teacher) by engaging in reasoning, questioning, and logic to sequentially make connections about the content and through this process find the predetermined correct answer. For example: for students to determine the effect of posture and speed of movement on the heart rate, the teacher gives the students a series of physical tasks to complete. Taking their heart rate when laying down, sitting up, standing up, walking around the gym, fast walk, jog, and after running around the gym. Students then participate in volleyball, flag football, basketball, tennis, etc. activities. Students answer questions regarding how their heart rate changed during each task. They are told to draw a conclusion based on their experience and the relationship between their heart rate and exercise patterns. Students will realize which of these exercises are beneficial to increasing their endurance. The teacher never told the students which exercises would help increase their endurance, but while answering questions the students asked questions while investigating, and came to the conclusion on their own.

\section{Question 11}

a. What teaching style does the above example/method best represent?

b. Do you use this teaching style when teaching any of your units? Yes No

If you answered "Yes," please answer "c" and then move to the next section. If you answered "No" answer "d" and then move to the next section.

c. Please list the unit and how many lessons per unit do you use this style?

UnitI use this teaching style times out of lessons.

UnitI use this teaching style times out of lessons.

UnitI use this teaching style times out of lessons.

d. Please list the reasons why you do not use this teaching style.

Please complete the following information about yourself.

1. I am years old.

2. I am (a)Male: (b)Female:

3. I have taught physical education for 4. I have taught (a) Elementary P.E. for years before this year. years; (c) High School P.E. for years; Middle School P.E. for (please years; other years explain)

5. I have coached (a) gender

(b) (select varsity/ junior varsity/other) 
(c) (list sports)

For (d) ___ years at___ (e) level (for example " I have coached

Girl's Varsity Soccer for 3 Years at the High School Level')

6. My ethnicity is (a)

7. Please check all applicable boxes.

_ (a) I received an undergraduate degree and credential in Physical Education or Kinesiology.

_ (b) I received a Post Graduate degree and credential in Physical Education or Kinesiology. SSAT)

(c) I received a Supplementary Credential in Physical Education (Praxis or

_(d) I earned a teaching credential in another subject area (Please list the $\operatorname{area}(\mathbf{s}))$

_ (e) I have recently attended Physical Education Workshops/Conferences

(Please list all workshops/conferences attended and the year attended)

_ (f) The last Physical Education Workshop/Conference I attended was 5 + years ago. (Please explain the reason for no longer attending. )

8. Have you had any formal training in teaching styles? (a) Yes (b) No

9. If "Yes" please answer question \#10. If "No" Please move to the next section.

I have received (please check all boxes that apply)

10. Formal Training while

_ (a) attending a workshop/conference session.

- (b) attending an undergraduate class where the entire class was devoted to the topic.

_ (c) attending an undergraduate class where a segment within the class was devoted to the topic.

_ (d) the entire undergraduate curriculum infused the topic across all/most of the classes.

_ (e) attending a graduate class where the entire class topic was devoted to the topic. _ (f)attending a graduate class where a segment within the class was devoted to the topic.

_ (g) the entire graduate curriculum infused the topic across all/most of the classes. Thank you very much for your participation! 


\section{APPENDIX C}

$\underline{\text { Table } 13}$

\section{$\underline{\text { Overall Results }}$}

\begin{tabular}{|c|c|c|c|}
\hline SPECTRUM STYLES & $\begin{array}{l}\text { HOW MANY TEACHERS COULD } \\
\text { CORRECTLY RECOGNIZE STYLE } \\
\text { DESCRIPTORS? }\end{array}$ & $\begin{array}{l}\text { WHAT UNITS AND HOW } \\
\text { MANY LESSONS DID THEY } \\
\text { USE THE STYLES IN? }\end{array}$ & $\begin{array}{l}\text { WHAT WERE THE REASONS THE } \\
\text { STYLES WERE/WERE NOT USED? }\end{array}$ \\
\hline PRACTICE STYLE & $\begin{array}{l}\text { ALL } 6 \text { TEACHERS COULD } \\
\text { RECOGNIZE THIS STYLE } \\
\text { DESCRIPTOR }\end{array}$ & $\begin{array}{l}\text { FOUR TEACHERS REPORTED } \\
\text { USING THIS STYLE IN THE } \\
\text { FOLLOWING UNITS/LESSONS: } \\
\text { BASKETBALL 5/10 } \\
\text { SOCCER } 6 / 10 \\
\text { FITNESS } 15-30 \\
\text { BASKET BALL 5-10 }\end{array}$ & $\begin{array}{l}2 \text { TEACHERS DID NOT USE THIS } \\
\text { STYLE STATING REASONS OF } \\
\text { TIME/AND CLASS SIZE }\end{array}$ \\
\hline GUIDED DISCOVERY & 5/6 TEACHERS COULD & TWO TEACHERS REPORTED & 4 TEACHERS DID NOT USE THIS \\
\hline STYLE & $\begin{array}{l}\text { RECOGNIZE THIS STYLE } \\
\text { DESCRIPTOR }\end{array}$ & $\begin{array}{l}\text { USING THIS STYLE IN THE } \\
\text { FOLLOWING UNITS; } \\
\text { BOWLING 5/30 } \\
\text { TRACK AND FIELD 5/10 }\end{array}$ & $\begin{array}{l}\text { STYLE STATING REASONS OF } \\
\text { TIME/AND CLASS SIZE }\end{array}$ \\
\hline SELF TEACHING STYLE & $\begin{array}{l}\text { 4/6 TEACHERS COULD } \\
\text { RECOGNIZE THIS STYLE } \\
\text { DESCRIPTOR }\end{array}$ & $\begin{array}{l}\text { NO TEACHERS REPORTED } \\
\text { USING THIS STYLE }\end{array}$ & $\begin{array}{l}6 \text { TEACHERS DID NOT USE THIS } \\
\text { STYLE STATING REASONS OF } \\
\text { STUDENT MATURITY, AND } \\
\text { TEACHER LIABILITY }\end{array}$ \\
\hline RECIPROCAL STYLE & $\begin{array}{l}\text { 5/6 TEACHERS COULD } \\
\text { RECOGNIZE THIS STYLE } \\
\text { DESCRIPTOR }\end{array}$ & $\begin{array}{l}\text { FIVE TEACHERS REPORTED } \\
\text { USING THIS STYLE IN THE } \\
\text { FOLLOWING UNITS; } \\
\text { TENNIS } 5 / 6 \\
\text { GOLF } 4 / 8 \\
\text { BASKETBALL } 5 / 10 \\
\text { TENNIS } 3 / 6 \\
\text { DANCE } 5 / 10\end{array}$ & $\begin{array}{l}1 \text { TEACHER DID NOT USE THIS } \\
\text { STYLE STATING REASONS OF } \\
\text { NOT CONDUCIVE TO PHYSICAL } \\
\text { EDUCATION }\end{array}$ \\
\hline LEARNER-INITIATED & 5/6 TEACHERS COULD & NO TEACHERS REPORTED & 6 TEACHERS DID NOT USE THIS \\
\hline STYLE & $\begin{array}{l}\text { RECOGNIZE THIS STYLE } \\
\text { DESCRIPTOR }\end{array}$ & USING THIS STYLE & $\begin{array}{l}\text { STYLE STATING REASONS OF } \\
\text { CLASS TIME AND CLASS SIZE } \\
\text { AND NOT COUNDICIVE TO PE. }\end{array}$ \\
\hline $\begin{array}{l}\text { LEARNER DESIGNED } \\
\text { INDIVIDUAL STYLE }\end{array}$ & $\begin{array}{l}\text { 5/6 TEACHERS COULD } \\
\text { RECOGNIZE THIS STYLE } \\
\text { DESCRIPTOR }\end{array}$ & $\begin{array}{l}\text { NO TEACHERS REPORTED } \\
\text { USING THIS STYLE }\end{array}$ & $\begin{array}{l}6 \text { TEACHERS DID NOT USE THIS } \\
\text { STYLE STATING REASONS OF } \\
\text { CLASS TIME AND CLASS SIZE } \\
\text { AND NOT COUNDICIVE TO PE. }\end{array}$ \\
\hline SELF CHECK STYLE & $\begin{array}{l}\text { 6/6 TEACHERS COULD } \\
\text { RECOGNIZE THIS STYLE } \\
\text { DESCRIPTOR }\end{array}$ & $\begin{array}{l}\text { ALL } 6 \text { TEACHERS REPORTED } \\
\text { USING THIS STYLE IN THE } \\
\text { FOLLOWING UNITS: } \\
\text { TENNIS } 5 / 10 \\
\text { BASKETBALL } 1 / 10 \\
\text { TENNIS } 3 / 6 \\
\text { SOCCER } 5 / 10 \\
\text { BOWLING } 25 / 30 \\
\text { BASKETBALL } 3 / 10\end{array}$ & N/A \\
\hline INCLUSION STYLE & $\begin{array}{l}\text { 5/6 TEACHERS COULD } \\
\text { RECOGNIZE THIS STYLE } \\
\text { DESCRIPTOR }\end{array}$ & $\begin{array}{l}2 \text { TEACHERS REPORTED } \\
\text { USING THIS STYLE IN THE } \\
\text { FOLLOWING UNITS: } \\
\text { TENNIS } 2 / 10 \\
\text { INLINE-SKATING } 5 / 10\end{array}$ & $\begin{array}{l}4 \text { TEACHERS REPORTED NOT } \\
\text { USING THIS STYLE STATING THE } \\
\text { REASONS THAT THIS STYLE } \\
\text { WOULD BE MORE APPLICABLE } \\
\text { TO SPECIAL EDUCATION } \\
\text { STUDENTS }\end{array}$ \\
\hline $\begin{array}{l}\text { DIVERGENT } \\
\text { DISCOVERY STYLE }\end{array}$ & $\begin{array}{l}\text { 5/6 TEACHERS COULD } \\
\text { RECOGNIZE THIS STYLE } \\
\text { DESCRIPTOR }\end{array}$ & $\begin{array}{l}\text { NO TEACHERS REPORTED } \\
\text { USING THIS STYLE }\end{array}$ & $\begin{array}{l}6 \text { TEACHERS REPORTED NOT } \\
\text { USING THIS STYLE STATING } \\
\text { REASONS OF CLASS SIZES AND } \\
\text { CLASS TIME }\end{array}$ \\
\hline COMMAND STYLE & $\begin{array}{l}\text { 6/6 TEACHERS COULD } \\
\text { RECOGNIZE THIS STYLE } \\
\text { DESCRIPTOR }\end{array}$ & $\begin{array}{l}\text { ALL } 6 \text { TEACHERS REPORTED } \\
\text { USING THIS STYLE IN THE } \\
\text { FOLLOWING UNITS: } \\
\text { KARATE } 8 / 10 \\
\text { GYMNASTICS } 3 / 6 \\
\text { STRETCHING } 10 / 10 \\
\text { WARM-UPS } 10 / 30 \\
\text { FITNESS } 10 / 30 \\
\text { FITNESS } 10 / 20\end{array}$ & N/A \\
\hline $\begin{array}{l}\text { CONVERGENT } \\
\text { DISCOVERY STYLE }\end{array}$ & $\begin{array}{l}\text { 6/6 TEACHERS COULD } \\
\text { RECOGNIZE THIS STYLE } \\
\text { DESCRIPTOR }\end{array}$ & $\begin{array}{l}1 \text { TEACHER REPORTED USING } \\
\text { THIS STYLE IN THE } \\
\text { FOLLOWING UNIT: } \\
\text { FITNESS } 5 / 25\end{array}$ & $\begin{array}{l}5 \text { TEACHERS REPORTED NOT } \\
\text { USING THIS STYLE STATING } \\
\text { CLASS SIZE AND CLASS TIME }\end{array}$ \\
\hline
\end{tabular}


